\title{
Credit Supply: Are there negative spillovers from banks' proprietary trading?
}

Citation for published version (APA):

Kurz, M., \& Kleimeier, S. (2019). Credit Supply: Are there negative spillovers from banks' proprietary trading? Maastricht University, Graduate School of Business and Economics. GSBE Research Memoranda No. 005 https://doi.org/10.26481/umagsb.2019005

Document status and date:

Published: 07/02/2019

DOI:

10.26481/umagsb.2019005

Document Version:

Publisher's PDF, also known as Version of record

\section{Please check the document version of this publication:}

- A submitted manuscript is the version of the article upon submission and before peer-review. There can be important differences between the submitted version and the official published version of record.

People interested in the research are advised to contact the author for the final version of the publication, or visit the DOI to the publisher's website.

- The final author version and the galley proof are versions of the publication after peer review.

- The final published version features the final layout of the paper including the volume, issue and page numbers.

Link to publication

\footnotetext{
General rights rights.

- You may freely distribute the URL identifying the publication in the public portal. please follow below link for the End User Agreement:

www.umlib.nl/taverne-license

Take down policy

If you believe that this document breaches copyright please contact us at:

repository@maastrichtuniversity.nl

providing details and we will investigate your claim.
}

Copyright and moral rights for the publications made accessible in the public portal are retained by the authors and/or other copyright owners and it is a condition of accessing publications that users recognise and abide by the legal requirements associated with these

- Users may download and print one copy of any publication from the public portal for the purpose of private study or research.

- You may not further distribute the material or use it for any profit-making activity or commercial gain

If the publication is distributed under the terms of Article $25 \mathrm{fa}$ of the Dutch Copyright Act, indicated by the "Taverne" license above, 


\section{Maastricht University}

Michael Kurz, Stefanie Kleimeier

Credit Supply: Are there negative spillovers from banks' proprietary trading?

$\mathrm{RM} / 19 / 005$

\section{GSBE}

Maastricht University School of Business and Economics

Graduate School of Business and Economics

P.O Box 616

NL-6200 MD Maastricht

The Netherlands 


\title{
Credit Supply: Are there negative spillovers from banks' proprietary trading?
}

This version: January 31, 2019

\author{
Michael Kurz ${ }^{\mathrm{a}, *}$, Stefanie Kleimeier ${ }^{\mathrm{a}, \mathrm{b}, \mathrm{c}}$ \\ ${ }^{a}$ Risk Management Department, De Nederlandsche Bank N.V., The Netherlands \\ ${ }^{b}$ Department of Finance, Maastricht University, The Netherlands \\ ${ }^{c}$ Department of Accounting and Finance, Open Universiteit Heerlen, The Netherlands \\ ${ }^{d}$ University of Stellenbosh Business School, Bellville, South Africa
}

\begin{abstract}
Do banks that heavily engage in proprietary trading reduce credit supply relative to their non-trading peers? We answer this question by looking at credit provided by the 135 leading banks in the global corporate loan market between 2003 and 2016. We find that banks with greater trading expertise supply less credit during economically stable times than their non-trading peers and even less during crisis times. This double effect can be attributed to US banks. International banks only reduce their credit supply during crises. We show that these spillovers from trading to credit supply have adverse consequences for the real economy as firms' ability to invest in capital and expand their workforce is reduced. During a crisis, firms that rely on banks with high trading expertise are most severely affected. Overall, our results suggest that the mandates by global regulators to separate trading from commercial banking are well advised.

Keywords: Credit Supply, Proprietary Trading, International Lending, Banking, Corporate Loans

JEL Classification: G01, G21, G28
\end{abstract}

${ }^{*}$ Corresponding author: Risk Management Department, De Nederlandsche Bank N.V., Westeinde 1, 1017 ZN Amsterdam, The Netherlands. Email: m.w.d.kurz@dnb.nl

The authors would like to thank for very helpful comments and discussions: Stefan Hirth, Klaas Mulier, Paul Söderlind, Jaap Bos, Paulo Rodrigues, Peter Schotman, David Martinez-Miera, Thomas Post, Nagihan Mimiroglu, Runliang Li, the participants of the PhD Brown Bag Seminar at Maastricht University School of Business and Economics and the participants of the 15th Corporate Finance Day at Antwerp University. All errors are, of course, our own. The paper is based on one of the chapters of Michael's PhD thesis. Views expressed are those of the authors and do not necessarily reflect official positions of De Nederlandsche Bank. 


\section{Introduction}

Traditionally, banks are described as institutions that primarily accept deposits from households and provide loans. ${ }^{1}$ However, the business model of most large modern banks extends beyond commercial banking, as banks are heavily involved in financial markets through the origination, distribution, and trading of various kinds of securities. Since the 2007 financial crisis, the proprietary trading activities of banks have come under great scrutiny. The Volcker Rule in the US, the Vickers Report in the UK, and the Liikanen and European Commission proposals in the EU all aim to limit the risks believed to emanate from banks' trading activities by strictly separating trading from commercial banking business. ${ }^{2}$ The concern underpinning these rules is that banks take on large risky bets while relying on implicit or explicit government guarantees for cheap funding, and then threaten to discontinue to offer classic banking services. In particular, during a crisis, banks could be inclined to purchase securities for fire-sale prices, speculating on future returns during economic recovery, rather than providing loans to non-financial firms. On the one hand, such behavior by banks can support financial markets through the provision of liquidity. On the other hand, it could lead to a spillover of security price shocks to the real economy in the form of a credit crunch. ${ }^{3}$ Based on these considerations, we test two hypotheses: First, we test the hypothesis that banks with greater trading expertise supply the real economy with less credit relative to banks with lower trading expertise, especially during periods of crisis. Second, we test whether this lower credit supply leads to lower investments and lower employment growth in non-financial firms that depend on funding from banks with trading expertise. We use a global sample of bank-firm lending relationships along with firm- and bank-specific information covering 135 banks from 21 countries

\footnotetext{
${ }^{1}$ For example, the IMF writes in its Finance \& Development series "Back to Basics" that "[Banks'] primary role is to take in funds - called deposits - from those with money, pool them, and lend them to those who need funds". See Gobat (2012).

${ }^{2}$ See Lehmann (2016), Krahnen, Noth and Schüwer (2017)

${ }^{3}$ See Shleifer and Vishny (2010), Diamond and Rajan (2011), Arping (2013), Stein (2013), Boot and Ratnovski (2016). Besides spillovers, there are also concerns regarding the conflict of interest of banks engaging in proprietary trading and simultaneously advising clients on trading. For a comprehensive discussion on the US context, see, e.g., Merkley and Levin (2011).
} 
and their lending to 8,242 firms from 81 emerging and advanced economies over the period 2003 to 2016. We find evidence in support of both hypotheses, suggesting that regulators' concerns regarding proprietary trading are generally well founded. Hence, the regulations are an important and justified tool of economic policy, despite some negative implications for market-making and liquidity. We provide evidence for the existence of the negative real economic effects of proprietary trading that need to be taken into account by regulators when assessing the cost-benefit trade-off of the above regulations.

We contribute to the literature on this topic by analyzing a global sample of corporate loans, from 2003 to 2016, using the Thomson Reuters LPC DealScan database which we hand-match with Standard \& Poor's Compustat database to obtain bank and borrower characteristics. This allows us to also provide an estimate of the real economic effects in terms of investments and employment growth. More specifically, we show that banks that are heavily engaged in securities trading supply non-financial firms with roughly 19\% less credit compared to banks less heavily engaged in securities trading. That gap in credit supply increases even further during periods of crisis. We further demonstrate that the reduced credit supply of banks heavily engaged in securities trading has ramifications for their borrowers. Firms tend to invest less in capital and expand their workforce at a lower rate the more they depend on trading banks for financing. Moreover, our results indicate that while trading banks generally charge their borrowers higher spreads, they do not increase loan prices beyond what is observed from their non-trading peers during a crisis. By examining our global sample, we also find that while trading banks provide less credit overall, they tend to provide slightly more credit abroad. However, during a crisis, trading banks also cut their foreign lending to a greater extent than their non-trading peers. Finally, we show that there are significant differences between US banks and other banks in our sample. Non-US banks that are heavily engaged in securities trading only reduce their credit supply during a crisis, but not during economically stable times. However, for US banks that are heavily engaged in securities trading, we find a reduction in credit supply both during times of crisis and stability. 
Our empirical analysis tests predictions from a large base of theoretical literature on the role of banks' securities trading. Shleifer and Vishny (2010) and Diamond and Rajan (2011) argue that if funds are scarce, banks with greater trading expertise may reduce credit supply during a crisis as they redirect funds from lending to trading as the returns from investing in distressed assets are higher than the returns from lending. Arping (2013) makes a similar point and shows that while this behavior is individually optimal for banks from a profit-maximization perspective, it may hamper growth in the real economy as non-financial firms find it increasingly difficult to obtain credit financing. Even beyond periods of crisis, Boot and Ratnovski (2016) show in a theoretical model that the allocation of scarce funds to scalable short-term securities trading tends to reduce the availability of credit for non-scalable long-term relationship lending activities. This reallocation leads to insufficient incentives for banks to build and maintain long-term lending relationships. Moreover, Krahnen, Noth and Schüwer (2017) point out that universal banks that calculate their funding costs by averaging over the (high-risk) funding costs of trading and the (low-risk) funding costs of lending rather than using separate funding costs are biased towards trading. Averaging funding costs leads to a relative change in the profitability of trading and lending activities, where trading profitability increases as the average funding costs are below the trading funding costs and lending profitability decreases in an off-setting manner, as the average funding costs are higher than the lending funding costs. Hence, banks would be incentivized to cut funds for lending while increasing funds for trading. ${ }^{4}$ Neither of the described theoretical models nor the above-cost averaging argument depend on government guarantees for bank liabilities. However, in the presence of government guarantees, additional incentives would be provided for banks to increase their trading activities at the expense of relationship banking, as the funding costs of trading activities will not fully reflect the investment risks. ${ }^{5}$ In summary, all these theories support our first hypothesis, while Arping (2013) supports

\footnotetext{
${ }^{4}$ Krahnen et al. (2017) argue that this could easily be avoided through appropriate internal transfer pricing, but bank managers have personal incentives to apply cost averaging in the described way. This means that if managers have access to a bonus pool from one segment (either trading or banking) but not from another segment, cost averaging may increase the income of the managers at the expense of the shareholders.

${ }^{5}$ See Krahnen et al. (2017).
} 
our second hypothesis.

A large base of empirical literature documents the declining credit supply during the 2007-2009 financial crisis (see, e.g., Ivashina and Scharfstein (2010)). This decline is traced back to different bank lending channels, among which the most prominent is the bank lending channel of monetary policy (see, e.g., Bonaccorsi di Patti and Sette (2012), Jimenez, Ongena, Peydro and Saurina (2012), Jimenez, Ongena, Peydro and Saurina (2014)). Additionally, Cingano, Manaresi and Sette (2016), and Iyer, Peydro, da Rocha-Lopes and Schoar (2014) consider shocks to interbank lending, while Acharya, Eisert, Eufinger and Hirsch (2018) investigate the role of banks' exposure to crisisinduced sovereign risk thorough bond holdings. Finally, Abbassi, Iyer, Peydro and Tous (2016) investigate the trading channel that also drives our analysis. For the German banking market, Abbassi et al. (2016) show that those banks with trading expertise reduce lending more than banks without trading expertise during the financial crisis and redirect internal funds to buy stressed assets for fire-sale prices. The authors have access to a unique central bank dataset, including the German credit register and the European security-level holdings database, and are therefore able to provide security-specific evidence on trading decisions. While Abbassi et al. (2016) focus mostly on trading, they also provide some evidence that higher trading expertise goes hand-in-hand with lower credit supply provided by German banks to German firms. Thus, the global dimension of the trading-credit supply link and its real economic effects remain unexplored. Our analysis fills this gap.

\section{Empirical Framework}

Our aim is to investigate whether banks with extensive trading operations provide fewer loans in the corporate loan market than banks without or less extensive trading operations. To answer this question, we apply a modified version of the Khwaja and Mian (2008) regression specification. Khwaja and Mian (2008) consider an economy in which firms borrow from multiple banks. Such an economy may experience two kinds of observationally equivalent shocks to bank lending: firm- 
specific credit demand shocks and bank-specific credit supply shocks. Credit demand shocks reflect unobserved changes to firms' fundamentals such as shocks to productivity or shocks to customer demand. Credit supply shocks reflect changes in banks' funding situation such as variations in the availability of deposits or short-term liabilities or, as is the focus in this paper, redirection of available funds from corporate lending to proprietary trading. Therefore, it necessary to use an econometric specification that allows us to isolate the relevant credit supply shock.

The main idea of the Khwaja and Mian (2008) approach is the use of matched bank-borrower data to achieve this by controlling for unobserved credit effects to identify supply effects. Initially, we estimate the following model:

$$
\begin{array}{r}
\Delta \log \left({\text { LoanVolume })_{i j t}=\beta \times \text { Trading }_{i}}+\phi \times F S I_{i t}+\xi \times\left(\text { Trading }_{i} \times F S I_{i t}\right)\right. \\
+\boldsymbol{\delta} \times \mathbf{X}_{\mathbf{i t}}+\gamma_{j t}+\gamma_{\text {bank country } t}+v_{i j t},
\end{array}
$$

where the dependent variable is the change in the logarithm of the loan volume by bank $i$ to borrower $j$ in year $t$. While Equation (1) is represented in reduced form, Khwaja and Mian (2008) show that it can be derived as an equilibrium condition by explicitly modeling credit supply and demand schedules. We include borrower*time fixed effects $\gamma_{j t}$ to account for time-varying, unobserved heterogeneity in borrower characteristics that proxy for credit demand. Hence, we compare the changes in the loan volume extended to the same borrower in the same year across different banks. Our specification also includes bank country*time fixed effects $\gamma_{\text {bank country } t}$ to account for time-varying macroeconomic conditions and regulatory environments in the banks' country of incorporation. Moreover, we include a vector $\mathbf{X}_{\mathbf{i t}}$ of bank control variables in our model where $\delta$ denotes the corresponding vector of the regression coefficients.

Our coefficient of interest is $\beta$, where Trading $_{i}$ proxies for bank $i$ 's trading expertise. In line with our first hypothesis, we expect $\beta$ to be negative, indicating that banks with greater trading expertise reduce credit supply to their corporate borrowers. We expect this effect to be stronger 
during periods of crisis than in periods of stability. We therefore interact Trading $_{i}$ with a Financial Stress Indicator $F S I_{i t}$ and expect a negative value for $\xi$.

Besides the financial effects, i.e., the effects of banks' trading activities on the loan volume granted, we also investigate the real economic effects of banks' trading activities. Following the approach in Khwaja and Mian (2008), Acharya et al. (2018), and Cingano et al. (2016), we estimate the following model:

$$
\begin{aligned}
y_{j t}=\phi_{\text {Country }}+\phi_{\text {Industry }}+\phi_{t}+ & +\times \overline{\text { Exposure }}_{j t}+\Phi \times F S I_{j t} \\
& +\lambda \times \overline{\text { Exposure }}_{j t} \times F S I_{j t}+\boldsymbol{\Psi} \times \mathbf{F}_{\mathbf{j t}-\mathbf{1}}+u_{j t},
\end{aligned}
$$

where $y_{j t}$ refers either to the capital expenditure or employment growth of borrower $j$ in year $t$. $\mathbf{F}_{\mathbf{j t}-\mathbf{1}}$ is a matrix of the borrower control variables. $\phi_{\text {Country }}, \phi_{\text {Industry }}$, and $\phi_{t}$ denote the country, industry, and year dummies respectively. $\overline{\text { Exposure }}_{j t}$ is a proxy for exposure of a borrower to the trading expertise of its lender banks. In line with our second hypothesis, we expect $\theta$ to be negative, indicating that firms with a greater dependency on trading banks suffer from a more restrictive credit supply and thus exhibit lower capital expenditures and employment growth.

There are different channels through which exposure to trading by lenders can affect borrowers, and we differentiate between the three channels in our empirical model:

$$
\begin{aligned}
\overline{\text { Trading Exposure }}_{j t} & =\sum_{i} \omega_{j i t} \times \mathbb{1}_{\left[\text {TradingExpertise }_{i}\right]} \\
\overline{\text { Trading Bank FSI Exposure }}_{j t} & =\sum_{i} \omega_{j i t} \times \mathbb{1}_{\left[\text {TradingExpertise }_{i}\right]} \times F S I_{i t} \\
\overline{\text { Bank FSI Exposure }}_{j t} & =\sum_{i} \omega_{j i t} \times F S I_{i t}
\end{aligned}
$$

where $\omega_{j i t}$ is equal to the share of credit granted by each bank $i$ to borrower $j$ in year $t$ and $\left.\mathbb{1}_{[\text {TradingExpertise }}\right]$ equals one if bank $i$ is considered as having trading expertise and zero otherwise. 
$F S I_{i t}$ is a Financial Stress Index, measuring the level of stress in the financial market of bank $i$ 's country of incorporation. Thus, $\overline{\text { Trading Exposure }}_{j t}$ is simply the share of loans granted to a borrower by banks with trading expertise. Meanwhile, by using $\overline{\text { Trading Bank FSI Exposure }}_{j t}$ we can capture exposure to financial market stress in the country of incorporation of the lender banks with trading expertise. Finally, with $\overline{B a n k F S I ~ E x p o s u r e}_{j t}$, we have a measure of exposure to financial stress in a bank's country of incorporation, unconditional on trading expertise.

Each of the measures in Equations (3) to (5) captures a different channel by which non-financial firms could be affected by the capital market operations of their banks. Equation (3) captures the direct effect of exposure to banks with trading expertise. Equation (4) uses the same exposure but further weights it by the current condition of the bank's home financial market. This equation clearly captures the idea that banks with trading expertise would buy assets at fire-sale prices in times of financial market stress. ${ }^{6}$ The last measure in Equation (5) moves away from the idea of explicitly discriminating between banks with or without trading expertise simply by capturing exposure to the current condition of the bank's home financial market.

\section{Data}

To estimate the two models, we need information on the banks' lending and trading activities as well as the borrowers' exposure to their lenders' trading activities. Our primary sources of information are the Thomson Reuters LPC DealScan database, which provides extensive coverage of the global corporate loan market, and Standard \& Poor's Compustat database, which provides extensive information on bank and borrower characteristics. Since LPC DealScan and Compustat do not share any common identifier, we hand-match all borrower, bank, and loan information. We collect information on corporate loans extended by 136 major banks in 21 countries between 2003 and 2016 to 8,242 non-financial firms in 81 countries, including advanced and emerging economies. ${ }^{7}$

\footnotetext{
${ }^{6}$ See Abbassi et al. (2016), Diamond and Rajan (2011), Arping (2013).

${ }^{7}$ Consistent with the literature, we aggregate all loans to each bank's parent company (see, e.g., Sufi (2007)) and track bank mergers over our sample period (see, e.g., Schwert (2018)).
} 
Our banks are based in the US, Canada, the UK, Austria, Belgium, Denmark, France, Germany, Ireland, Italy, Netherlands, Spain, Sweden, Switzerland, China, Hong Kong, Taiwan, South Korea, Singapore, Japan, Brazil, and Australia.

In model (1), our dependent variable is the change in the logarithm of the loan volume by bank $i$ to borrower $j$ in year $t$. In most uses of the Khwaja and Mian (2008) specification, the left-hand side variable is measured using detailed information from national credit registers. However, our corporate loan data differs from such credit register data in two important ways. First, we cannot observe changes in a particular loan over time, since we only observe loans at the time of their origination. Second, the loans in our sample tend to have long maturities. These two properties of our loans imply that for a large number of firms, there is no meaningful time-series variation in the bank-firm loan volumes. To address this issue, we follow Acharya et al. (2018) and aggregate firms into clusters, applying the Khwaja and Mian (2008) estimator to a panel of bank-firm cluster relationships. ${ }^{8,9}$

Similar to Acharya et al. (2018), we form clusters based on the country of incorporation, the two-digit SIC code, and the median EBITDA interest coverage ratio. We expect firms that are incorporated in the same country and that are active in the same industry to share sufficiently similar characteristics. Furthermore, credit ratings are an important determinant in bank lending. Therefore, firms with the same rating will have similar access to the loan market or other sources of financing (see, e.g., Diamond (1991), Erel, Julio, Kim and Weisbach (2011)). Thus, we further match firms in the country-industry clusters based on their median interest coverage ratio. In sum-

\footnotetext{
${ }^{8}$ Veredas and Petkovic (2010) have shown that aggregating individual observation into groups into panel datasets with a low-time frequency does not affect the model structure. The estimated coefficients remain unbiased and correspond to the coefficients of the individual firm-level regressions. However, heteroscedasticity is introduced due to the aggregation of individual firms. Both statements are easy to verify using standard arguments (see Appendix A.2). Thus, for model (1), we cluster standard errors at the bank and firm-cluster level, and for model (2), we cluster standard errors at the firm-cluster level.

${ }^{9}$ Aggregating individual observations into groups may also raise concerns regarding the Simpson's paradoxon (see Simpson (1951), Blyth (1972)), i.e., the phenomenon that a trend may appear within groups of the data but reverses if the individual observations in the groups are aggregated. However, the inclusion of group fixed effects that act as group-specific intercepts in our regression models prevents trends in the groups from reversing after aggregation of the observation.
} 
mary, our dependent variable $\Delta \log \left(\right.$ LoanVolume $\left._{i j t}\right)$ is the change in the logarithm of the total USD volume of credit granted by bank $i$ to all firms in cluster $j$ in year $t$. This leaves us with 24,056 unique bank-firm cluster connections.

Our main independent variable is Trading $_{i}$, which reflects the trading expertise of bank $i$. Consistent with the approach used in Abbassi et al. (2016), we rely on the notion that banks, in order to maintain or build a strong presence in securities trading and thus to have trading expertise, require a specific infrastructure. Arguably, direct trading memberships at important securities exchanges are among the most relevant aspects of such trading infrastructure, as they allow for direct access to the trading floors and trading and clearing systems of the respective exchanges without the need of intermediate brokers.

Thus, for each bank in our sample, we count the total number of trading memberships at Euronext (the European multi-country exchange), the London Exchange, NYSE, NASDAQ, the Toronto Exchange, the Japan Exchange (covering all Japanese exchanges), the Hong Kong Exchange, the Shanghai Exchange, BMnF Bovespa (Brazil), the Australian Securities Exchange, and the Deutsche Börse (the German Exchange). Each of these exchanges has been listed as one of the ten largest exchanges in terms of market capitalization at least once during our sample period. A bank is considered a trading member of either of these exchanges if it has purchased the right to directly access the trading floor. If a bank has access to more than one market of the same exchange (equity, fixedincome, and/or derivatives), we count this as one membership at the relevant exchange. Note that it is not necessary for foreign banks to possess a banking license in the relevant country to purchase a membership.

We hand-collect the trading membership information from the websites of the relevant exchanges and company reports. While all banks in our sample offer trading services to their clients, it is not necessary for a bank to possess a trading membership at any exchange to offer such services. Such a bank could handle all trading, including trading on behalf of clients via external broker-dealers. Even if a bank were to purchase a trading membership to more easily offer trading services to 
clients, this would hardly require more than a single membership at a major exchange. Thus, we would expect banks with a large number of exchange memberships to have strong trading operations and consequently a higher level of trading expertise. Therefore, next to a simple count variable of the number of exchange memberships as a proxy for trading, we consider two dummies: one identifying banks with at least one membership, the other identifying banks with more than two memberships. The latter category reflects the idea that banks with only one or two memberships use those primarily for client-related trading, while true proprietary traders require a larger number of trading memberships in various markets.

Consistent with our line of argument, Figure 1 additionally indicates that the USD volume of a bank's trading account as a fraction of its total assets tends to be larger the more trading memberships the bank possesses. We estimate a correlation coefficient of 0.6 between the two variables, which is statistically significant at the one percent level. A larger trading account volume indicates greater securities trading on part of the the banks.

Our notion of interpreting greater activity as a sign of greater expertise in trading is consistent with a large base of theoretical and empirical literature on organizational learning-by-doing (see, e.g., Jarmin (1994), Thompson (2010), Argote and Miron-Spektor (2011)). Note that for all panels of Figure 1, there is an upward jump in trading securities for banks with more than two memberships. This supports the previously outlined approach of defining a trading expertise dummy that equals one if a bank has more than two memberships and zero otherwise.

Ideally, we would like to observe when banks are buying or selling securities. Changes in the USD volume of a bank's trading account cannot be used to identify when banks are trading. Since the volume is the product of price and quantity, increases in quantity due to banks' purchases of securities could be offset by the prices of the same securities falling during crisis. 
Figure 1: Trading Account and Trading Memberships

Notes: In the boxplot, we show the volume of the securities trading account as a fraction of the total assets for different counts of trading memberships at exchanges. The sample consists of 136 major banks based in 21 countries between 2003 and 2016. Panel a) shows the boxplot for the full sample period, and panels b) to d) show the boxplots for the various sub-periods. The continuous variable (y-axis) represents the USD volume of the trading/dealing account divided by the USD (book value) of the total assets. The categorical variable (x-axis) represents the number of trading memberships at major exchanges. We count memberships at Euronext (the European multi-country exchange), the London Exchange, NYSE, NASDAQ, the Toronto Exchange, the Japan Exchange (covering all Japanese exchanges), the Hong Kong Exchange, the Shanghai Exchange, BMnF Bovespa (Brazil), the Australian Securities Exchange, and the Deutsche Börse (the German Exchange).

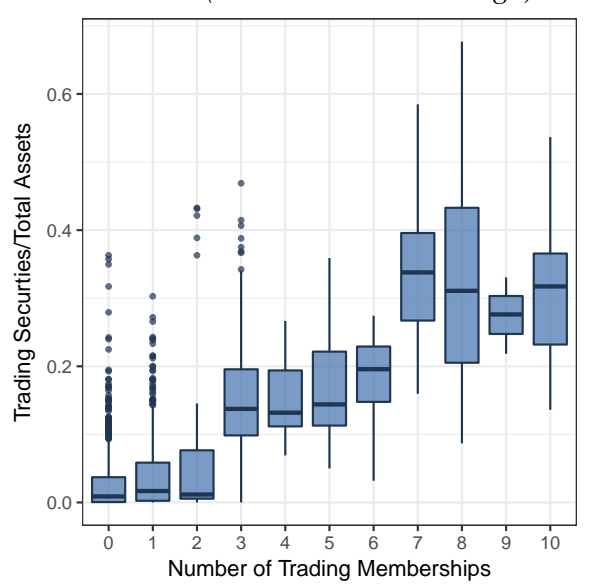

a) Full sample period

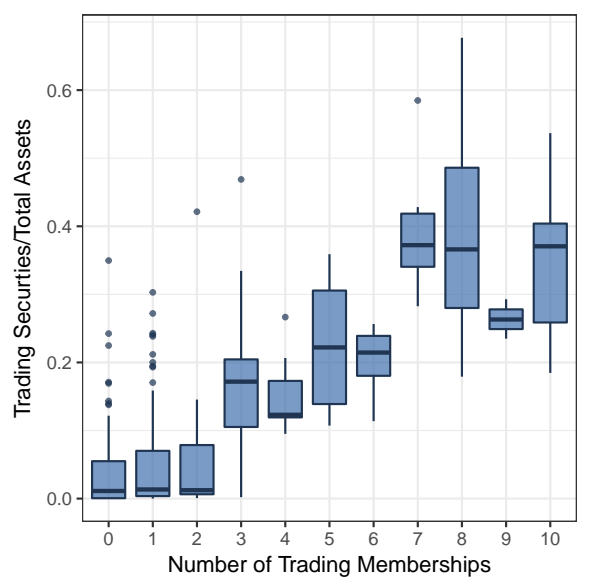

c) Crisis period

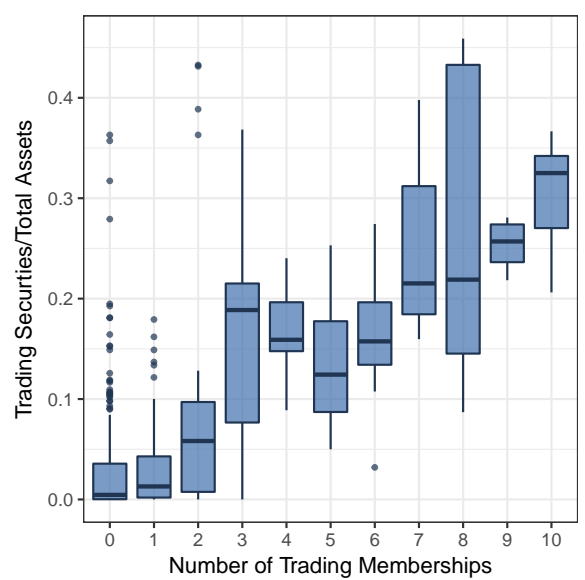

b) Pre-Crisis period

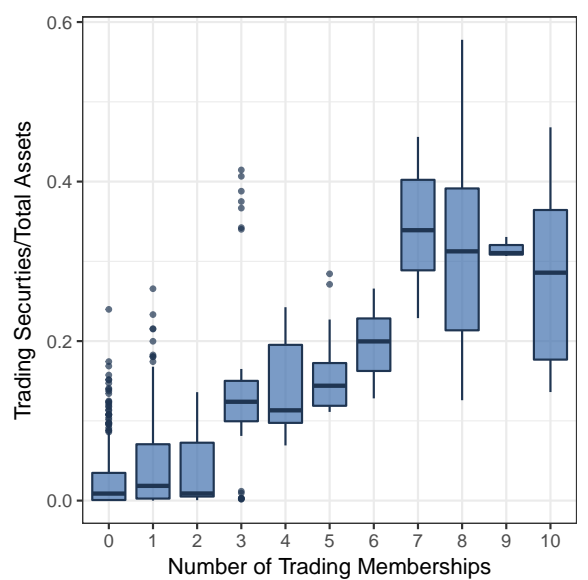

d) Post-crisis period

With respect to $F S I_{i t}$, we consider three different measures. First, we consider a simple dummy variable - Crisis - indicating the crisis period from 2007 to 2009. Note that if we include the crisis dummy, we must adapt the specification of the fixed effects in model (1). Accordingly, we 
use firm cluster and bank country fixed effects rather than firm cluster-year and bank country-year fixed effects. Second, we augment our dataset with the Financial Stress Index - Financial Stress $s_{i t}$ - developed by the US Office for Financial Research. ${ }^{10}$ The Financial Stress Index is a continuous measure of stress in financial markets, taking into account contributions to stress from credit markets, equity valuations, funding, safe assets, and volatility. The index is centered on zero, where positive values indicate increased stress and negative values indicate relaxation. Thus, using the index, we can obtain a more granular view of the financial market conditions over time compared to a simple crisis dummy. Furthermore, since the index distinguishes three different world regions (the US, other advanced economies, and emerging economies), we can take into account that emerging economies were less affected by the 2007-2009 financial crisis than advanced economies were. This impact is documented in, e.g., Blanchard, Das and Faruqee (2010). In particular, Emerging Asia was affected to a lesser extent than advanced economies were (see, e.g., Goldstein and Xie (2009), Keat (2009)). Thus, we feel it is important to take these differences into account.

We use price and market capitalization data from Standard \& Poor's Global Equity country indices to construct a measure of capital market conditions:

$$
\begin{aligned}
\text { Capital Market }_{i t} & = \\
& -1 \times\left(\frac{\text { MCap }_{\text {Home }, t} \times \text { Price }_{\text {Home } t}+\sum_{k=1, k \neq H o m e}^{K} \text { MCap }_{k t} \times \text { Price }_{k t}}{\text { MCap }_{\text {Home }}+\sum_{k=1, k \neq H o m e}^{K} M C a p_{k t}}\right)
\end{aligned}
$$

where $M C a p_{k t}$ is the total market capitalization of country $k$ 's stock market, and Price $k t$ is the value of the Standard \& Poor's Global Equity Index for country $k$. The $k$ indexes countries in which bank $i$ possesses trading memberships and Home indexes a bank's country of incorporation. We multiply the right-hand side of the equation by -1 to obtain the same directionality as the previously described Financial Stress Index, i.e., due to the multiplication by -1 , high values of

\footnotetext{
${ }^{10}$ See Monin (2017) for details on the computation of the index. The US Office for Financial Research was created by the Dodd-Frank Act of 2010 and is tasked with observing US and global financial markets conditions to provide regulators with timely market intelligence.
} 
Capital Market it $_{\text {indicate low prices and vice versa. }}$

Finally, the bank control variables $\mathbf{X}_{\mathbf{i t}}$ in model (1) capture differences in bank size, profitability, and funding. The control variables comprise the logarithm of the book value total assets, ROA, capital ratio, liquidity ratio, and the Loans-to-Deposits Ratio. The data for these controls is obtained from Compustat. ROA is computed as the income before extraordinary items divided by the book value of total assets. The capital ratio is the ratio of the book value of common equity to the book value of total assets. The liquidity ratio is computed as the ratio of cash to total assets. The Loansto-Deposits Ratio is computed as the ratio of total loans to total deposits.

In model (2), our dependent variables $y_{j t}$ are the capital expenditure and employment growth in year $t$ aggregated across all firms in cluster $j$. Our firm cluster controls $\mathbf{F}_{\mathbf{j t - 1}}$ comprise the logarithm of the book value of total assets, net debt-to-assets ratio, intangible assets-to-assets ratio, the change in cash and cash equivalents in year $t-1$ aggregated across all firms in cluster $j$. Net debt is the sum of short-term and long-term liabilities minus cash and cash equivalents. The inputs for our three exposure measures are derived from the trading expertise measures of model (1). Looking ahead to our results for model (1), we find that our simple dummy that indicates more than two trading memberships is most informative. We therefore utilize this dummy in our implementation of model (2).

\section{Summary Statistics}

We show summary statistics for our sample banks in Table 1 . The banks in our sample are large and rather similar in size. However, there is significant variation in both profitability measured by ROA and capitalization. The large variations in Total Loans and Trading Securities suggest differences in the business models of our sample banks. For the average bank in our sample, loans

account for roughly $50 \%$ of assets and trading securities account for roughly $9 \%$ of assets. However, there are banks with particularly large holdings in trading securities.

The number of trading memberships varies from non membership to memberships at all of the 
exchanges considered in our analysis, and the average bank possesses two memberships. The bottom row in Table 1 shows that $25 \%$ or 34 out of our 135 sample banks possess more than two trading memberships at the major exchanges considered in our analysis. However, these banks represent roughly $50 \%$ of the number of loans granted or $56 \%$ of the loan volume in our sample. We observe banks based in 21 countries, most of them located in North America, Europe, and Japan. In Table 2, we show the distribution of banks across countries and regions. Banks are similar in size and lending across regions. Banks in Europe and North America are particularly active in securities trading, with large numbers of exchange memberships. We observe a total of 8,242 firms, most of which are based in the US, the EU, and Japan. Table 3 shows a more detailed distribution of firms across countries. Roughly two-thirds of the firms in our sample are based in advanced economies and roughly one-third are based in emerging economies. We show the time series of the Financial Stress Index for the US, other advanced economies, and emerging economies in Figure 2. "Other advanced economies" comprises primarily Europe and Japan. An index value of zero suggests that stress is at normal levels, positive (negative) value indicate increased (decreased) stress. USA covers the US economy. The index clearly identifies the last financial crisis for all three regions, indicating extreme financial stress during that time period. In line with previous research the index clearly shows less financial stress in emerging economies compared to advanced economies (see, e.g., Blanchard et al. (2010), Goldstein and Xie (2009), Keat (2009)). The time series for the US and all other advanced economies almost completely overlap during the entire sample period. Both of these time series share a correlation coefficient of roughly 0.94 , indicating almost perfect co-movement. The correlation coefficient between the time series for the US and the emerging economies is 0.77 and for the EU and the emerging economies, the correlation coefficient is 0.84 . This suggests that a simple crisis dummy would be sufficient to capture the crisis timing globally, but not the severity of the impact. In terms of the severity of the impact of the crisis, it appears to be sufficient to distinguish between advanced and emerging economies. We now turn to the relevant firm clusters in the estimation of model (2). The firm clusters are formed based on 8,242 individual 
Table 1: Bank Characteristics

Notes: In this table, we show the summary statistics of the banks' characteristics for our 1,603 bank-year observations. The sample consists of 135 individual banks from 21 countries, examining the period 2003 to 2016. Annual data for all banks is obtained from Standard \& Poor's Compustat database. All the characteristics are converted from local currency to USD using the unweighted average of the daily exchange rates in the relevant year. Daily foreign currency exchange rates are obtained from Compustat. Total Assets is the book value of total assets. Trading Securities is USD volume of all trading and dealing accounts divided by total assets. Total Loans and Total Deposits are the book values of all loans granted to non-bank clients divided by total assets and all deposits received from non-bank clients divided by total assets, respectively. Accordingly, the Loans-to-Deposits Ratio is defined as the ratio of Total Loans to Total Deposits. The Capital Ratio is the ratio of the book value of the stockholders' equity to the book value of total assets. The Liquidity Ratio is computed as cash/total assets. \# Trading Memberships counts the number of trading memberships in the ten largest security exchanges worldwide and is measured by market volume. Trading Memberships is an indicator variable that is equal to one if a bank has at least one membership and zero otherwise. \# Trading Memberships $>2$ is an indicator variable that is equal to one if a bank has more than two trading memberships.

\begin{tabular}{|c|c|c|c|c|c|c|c|}
\hline Statistic & Mean & St. Dev. & Min & $\operatorname{Pctl}(25)$ & Median & $\operatorname{Pctl}(75)$ & Max \\
\hline $\log$ (Total Assets) & 12.491 & 1.286 & 10.632 & 11.306 & 12.435 & 13.600 & 14.898 \\
\hline Trading Securities & 0.087 & 0.116 & 0.000 & 0.003 & 0.033 & 0.130 & 0.677 \\
\hline ROA (in \%) & 0.582 & 0.543 & -1.146 & 0.275 & 0.564 & 0.947 & 1.760 \\
\hline Capital Ratio & 0.066 & 0.028 & 0.018 & 0.045 & 0.061 & 0.083 & 0.133 \\
\hline Liquidity Ratio & 0.038 & 0.033 & 0.005 & 0.014 & 0.027 & 0.052 & 0.125 \\
\hline Total Loans & 0.498 & 0.186 & 0.000 & 0.402 & 0.535 & 0.643 & 0.719 \\
\hline Total Deposits & 0.575 & 0.240 & 0.000 & 0.419 & 0.616 & 0.767 & 0.882 \\
\hline Loans-to-Deposits & 0.892 & 0.414 & 0.000 & 0.687 & 0.803 & 1.074 & 1.949 \\
\hline \# Trading Memberships & 2.025 & 2.865 & 0 & 0 & 1 & 2.8 & 10 \\
\hline Trading Memberships & 0.628 & \multicolumn{6}{|c|}{-} \\
\hline \# Trading Memberships $>2$ & 0.250 & \multicolumn{6}{|c|}{-} \\
\hline
\end{tabular}




\section{Table 2: Banks by Region/Country}

Notes: In the table, we present the number of banks per country/region and the corresponding mean values within a relevant country/region. For the larger regions (the US, other Advanced economies, and emerging economies), we also report the standard deviation within regions in parentheses. log(Total Assets) is the logarithm of the book value of total assets. \# Trading Memberships counts the number of trading memberships in the ten largest security exchanges worldwide measured by market volume. $\Delta \log ($ Loan Volume) is the year-on-year difference of the logarithm of the loan volume.

\begin{tabular}{lcccc}
\hline \hline Country/Region & \# of Banks & $\log$ (Total Assets) & \# Trading Memberships & $\Delta \log ($ Loan Volume $)$ \\
\hline US & 41 & 13.071 & 3.789 & 1.803 \\
& & $(1.273)$ & $(4.564)$ & $(2.476)$ \\
Other Advanced & 71 & 13.572 & 4.004 & 1.296 \\
& & $(1.064)$ & $(3.039)$ & $(2.150)$ \\
Canada & 5 & 13.045 & 3.554 & 1.678 \\
European Union & 32 & 13.868 & 4.833 & 1.249 \\
Switzerland & 3 & 13.925 & 9.939 & 1.504 \\
Japan & 23 & 13.108 & 1.308 & 1.263 \\
Australia & 7 & 12.777 & 0.993 & 0.876 \\
& & & & 0.568 \\
Emerging & 24 & 12.857 & 1.073 & $(1.421)$ \\
& & $(1.288)$ & $(1.117)$ & 0.627 \\
China & 13 & 13.992 & & 0.445 \\
Hong Kong & 2 & 11.397 & 1.885 & 0.591 \\
Singapore & 2 & 12.084 & 1.000 & 0.311 \\
South Korea & 4 & 12.294 & 0.000 & 0.426 \\
Taiwan & 2 & 11.352 & 0.000 & 0.586 \\
Brazil & 1 & 12.554 & 0.192 & 1.000 \\
\hline
\end{tabular}




\section{Table 3: Distribution of Borrowers by Country}

Notes: In this table, we present the distribution of borrower firms by country in our sample. The data for all firms is obtained from Standard \& Poor's Compustat database. We observe a total of 8,242 firms from 81 countries between 2003 and 2016.

\begin{tabular}{clc} 
Rank & Country & Number of Firms \\
\hline 1 & US & 3,755 \\
2 & Japan & 1,264 \\
3 & Canada & 480 \\
4 & United Kingdom & 425 \\
5 & Taiwan & 269 \\
6 & Australia & 220 \\
7 & France & 186 \\
8 & Germany & 174 \\
9 & India & 135 \\
10 & Hong Kong & 115 \\
11 & China & 89 \\
12 & Italy & 85 \\
13 & South Korea & 79 \\
14 & The Netherlands & 73 \\
15 & Spain & 68 \\
16 & Singapore & 59 \\
17 & Sweden & 56 \\
18 & Switzerland & 54 \\
19 & Norway & 53 \\
20 & Russia & 44 \\
21 & Finland & 42 \\
22 & Malaysia & 36 \\
23 & Brazil & 35 \\
24 & New Zealand & 34 \\
25 & Mexico & 31 \\
$26-81$ & Others & 381 \\
\hline & Total &
\end{tabular}


Figure 2: Is Financial Stress in Crisis Periods the Same Around the World?

Notes: In this figure, we show the value of the Financial Stress Index of the US Office of Financial Research. The index is a measure of systemic financial stress, capturing contributions to financial stress from credit, equity valuations, funding, safe assets, and volatility. An index value of zero suggests that stress is at normal levels, and a positive (negative) value indicates increased (decreased) stress. Other Advanced covers advanced economies other than the US, primarily the EU and Japan. Emerging covers emerging markets. For details on the index computation and coverage, see Monin (2017).
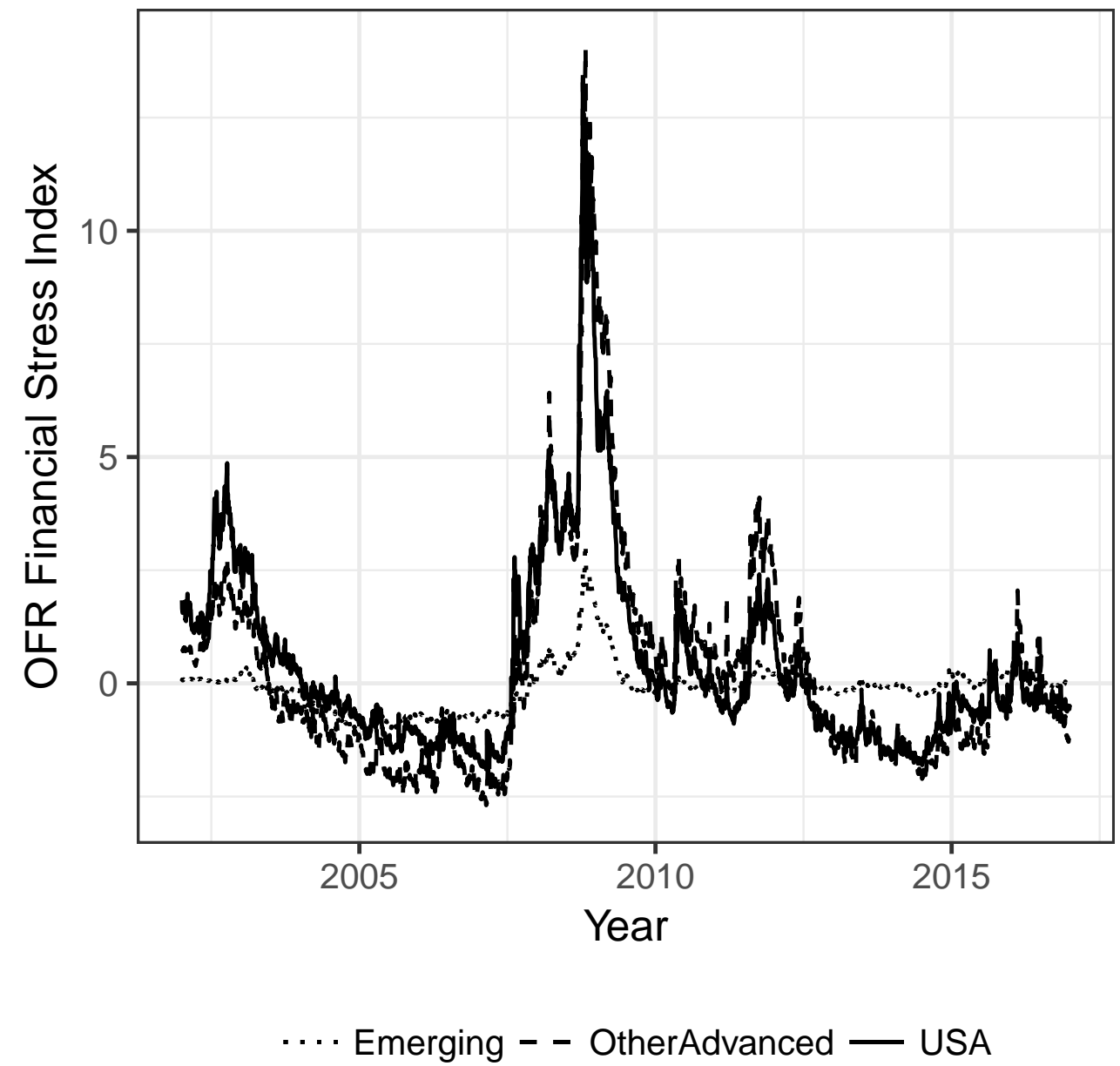
firms using the procedure outlined in the beginning of Section 3. We form, in total, 1,732 individual clusters, such that the average firm cluster consists of roughly five firms, each firm incorporated in the same country, active in the same industry, and within the same EBITDA interest coverage range. We show the summary statistics for the firm clusters in our sample in Table 4. The firm clusters in our sample are comparable but rather large in terms of the book value of total assets. However, the clusters are diverse in their leverage and their changes in cash holdings, with the net debt to assets ratios ranging from $4.3 \%$ to $68.2 \%$ and changes in cash as a share of assets ranging from $-5.3 \%$ to $+8.4 \%$. This clearly indicates a variation in the need of bank financing across our firm clusters.

The bottom three rows in Table 4 show the summary statistics for our measures for the exposure of firm clusters towards the trading expertise and financial market conditions of their respective lenders, as defined in Equations (3) - (5). The mean value of 0.45 for Trading Exposure implies that the average firm cluster in our sample receives $45 \%$ of its loans from banks with trading expertise. However, the degree of dependence varies significantly across firm clusters, with some clusters receiving none of their loans from banks with trading expertise and others receiving all of their loans from banks with trading expertise. Trading Bank FSI Exposure follows the same idea but also takes the level of financial stress in the relevant lender country into account. Thus, for each firm cluster, it represents a weighted average of the Financial Stress Index across the countries of the cluster's lenders with trading expertise, whereas the weights are the respective lending shares. $\overline{\text { Bank FSI Exposure }}$ is constructed in the same way but does not distinguish between lenders with and without trading expertise. Note that both measures can be negative or below -1 or +1 , as the Financial Stress Index is not restricted in its range. 


\section{Table 4: Characteristics of Firm Clusters}

Notes: In this table, we show the summary statistics for the firm clusters in our sample. The sample consists of 1,732 individual firm clusters from 81 countries, examining the period 2003 to 2016. The firm clusters are based on 8,242 individual firms, such that the average cluster consists of 4.76 firms. The clusters are formed by matching firms according to their (1) country, (2) industry, and (3) and EBITDA interest coverage, following the approach in Acharya et al. (2018). Data for all firms and foreign currency exchange rates is obtained from Standard \& Poors Compustat database. All non-USD values are converted to USD before any computations. log(Assets) is the logarithm of the book value of total assets. Capex refers to the capital expenditure. Employment Growth is the year-to-year change in the logarithm of the number of employees. Cash includes cash and cash equivalents. Net Debt is the sum of short-term and long-term debt minus cash and cash equivalents. Short-term Debt is all debt with a remaining time to maturity of up to one year, and Long-term Debt is all debt with a remaining time to maturity of more than one year. $\overline{\text { Trading Exposure, }} \overline{\text { Trading Bank FSI Exposure, }} \overline{\text { Bank FSI Exposure }}$ are defined in Equations (3) - (5).

\begin{tabular}{lccccccc}
\hline \hline Statistic & Mean & St. Dev. & Min & Pctl(25) & Median & Pctl(75) & Max \\
\hline Capex/Assets & 0.049 & 0.035 & 0.006 & 0.023 & 0.040 & 0.067 & 0.129 \\
Employment Growth & 0.028 & 0.155 & -0.297 & -0.041 & 0.015 & 0.087 & 0.387 \\
$\log$ (Assets) & 8.726 & 1.672 & 6.686 & 7.230 & 8.524 & 9.899 & 12.723 \\
$\Delta$ Cash/Assets & 0.008 & 0.036 & -0.053 & -0.013 & 0.004 & 0.027 & 0.084 \\
Net Debt/Assets & 0.397 & 0.176 & 0.043 & 0.285 & 0.410 & 0.528 & 0.682 \\
Intangible/Assets & 0.161 & 0.165 & 0.005 & 0.023 & 0.097 & 0.261 & 0.551 \\
Ebitda/Assets & 0.008 & 0.009 & 0.00004 & 0.001 & 0.004 & 0.012 & 0.027 \\
Trading Exposure & 0.450 & 0.300 & 0.000 & 0.191 & 0.510 & 0.650 & 1.000 \\
Trading Bank FSI Exposure & 0.080 & 1.070 & -1.910 & -0.545 & 0.000 & 1.700 & 5.560 \\
\hline Bank FSI Exposure & 0.17 & 1.84 & -1.910 & -1.093 & -0.090 & 0.699 & 5.560 \\
\hline
\end{tabular}




\section{Results}

\subsection{Credit Supply}

In this section, we present the results of the estimation of our model (1). The aim of this analysis is to test the hypothesis that banks with trading expertise supply fewer loans to non-financial firms than non-trading banks. We show the estimation results for model (1) in Table 5. Columns (1) to (3) show the results of our three trading expertise proxies but without the interaction with financial crisis measures. When proxying for trading expertise through a dummy that equals one if a bank has at least one trading membership at a securities exchange as in column (1), we do not find a statistically significant effect on credit supply. However, for both \# Trading Memberships and \# Trading Memberships $>2$, we find a negative, statistically significant effect. This supports our hypothesis that banks' trading activity negatively affects credit supply. The effect of \# Trading Memberships is smaller than that of \# Trading Memberships $>2$. The effects also differ largely in their economic significance. This lends support to our argument that a small number of trading memberships does not necessarily indicate trading expertise in large banking organizations. The coefficient associated with \# Trading Memberships indicates an average reduction in loan supply by approximately $2.66 \%$ per additional trading membership. The coefficient associated with \# Trading Memberships $>2$ indicates a reduction in the credit supply of approximately $19.18 \%$. Thus, both effects are not only statistically significant, but also economically meaningful.

We draw three conclusions from these results. First, the finding that the simple Trading Membership dummy turns out to be insignificant while the \# Trading Memberships $>2$ dummy turns out to be highly significant supports our earlier assertion that, especially for large banks, a single or a small number of trading memberships does not indicate specific trading expertise compared to other, similar large banks. A small number of trading memberships may indeed be purchased to service clients' trading needs or the banks' hedging needs rather than engaging in proprietary 
trading. ${ }^{11}$

Second, our dummy variables Trading Memberships and \# Trading Memberships $>2$ are constructed such that the \# Trading Memberships $>2$ banks are a subset of the Trading Membership banks. ${ }^{12}$ This finding suggests non-linearity in the relationship between changes in credit supply and the number of trading memberships. Such non-linearity also explains the rather large difference in magnitude between the effects of \# Trading Memberships and \# Trading Memberships > 2, as \# Trading Memberships implies a linear relationship. For this reason, we proceed with the \# Trading Memberships $>2$ dummy, i.e., the specification in column (3), as our baseline model. Finally, we conclude that our evidence as presented in Table 5 columns (1) to (3) supports the hypothesis that banks with greater trading expertise reduce credit supply.

Columns (4) to (6) contain the estimation results for the specifications, that include interactions between the \# Trading Memberships $>2$ dummy and the financial crisis measures, as shown in model (1). In column (4), we interact the \# Trading Memberships $>2$ dummy with the Financial Stress Index. Since the index is bank country-specific and time-varying we must drop the bank country-year fixed effects and include bank country fixed effects instead. The coefficient associated with \# Trading Memberships $>2$ now captures the effect of trading expertise for Financial Stress Index values of zero, i.e. in absence of either positive or negative stress. The negative and statistically significant coefficient associated with the interaction term indicates that banks with trading expertise tend to reduce their credit supply by an additional $3.25 \%$ per unit increase in financial stress compared to the $19 \%$ baseline reduction (statistics are approximate). In contrast, we do not find a significant effect for the Financial Stress Index alone. While evidently there was a great impact of the 2007 to 2009 financial crisis on the corporate loan market, this could suggest that

\footnotetext{
${ }^{11}$ It is worth noting that we differ in this regard from Abbassi et al. (2016), who only use a dummy variable at the largest fixed-income securities trading platform in the German market. Their sample of German banks is by far more heterogeneous in terms of bank size compared to our sample. Thus, in the case of Abbassi et al. (2016), for a comparatively small bank, a single trading membership may already indicate greater trading expertise, as the business model differs from the business model of the large banks in our sample.

${ }^{12}$ The Trading Membership dummy could also be called \# Trading Membership $>0$.
} 
the Financial Stress Index can capture the direct link between crisis and lending, but only through banks' securities trading activities.

In Figure 3, we visualize the marginal effect of \# Trading Memberships $>2$ for the observed range of values of the Financial Stress Index. ${ }^{13}$. The positive values of the index indicate financial market stress, and negative values indicate financial market relaxation (stabilizing conditions). The marginal effect is a downward slope, statistically significant, and negative, with a relatively narrow confidence interval across the whole range of Financial Stress Index values. This supports our earlier interpretation that banks with trading expertise tend to reduce credit supply even under favorable financial market conditions but reduce credit supply even further with increasing financial market stress. In the figure, we highlight the marginal effects for the zero values of the Financial Stress Index, its 2007 to 2009 crisis average, and its 2007 to 2009 crisis peak value. The corresponding economic effects are approximately $19 \%, 33 \%$, and $47.8 \%$, respectively.

The Financial Stress Index is not a crisis indicator in this sense. Only large values indicate a financial crisis, while the index fluctuates around zero throughout the business cycle. Thus, to more clearly isolate the impact of the financial crisis in column (6) of Table 5, we substitute the Financial Stress Index with a simple dummy variable that equals one during the crisis 2007 to 2009 and zero otherwise. Consequently, we cannot include either the firm cluster-year or bank country-year fixed effects in this specification. We instead use firm cluster and bank country fixed effects. This dummy can capture the effects of the financial crisis on credit supply more broadly and more directly than the Financial Stress Index. All effects in column (6) are negative and statistically significant. The results indicate that banks with trading expertise reduced their loan supply by approximately $46.23 \%$ during the financial crisis while banks without trading expertise reduced their loan supply only by approximately 29.69\%. The results in columns (4) and (6) support the hypothesis that banks with trading expertise reduce their loan supply more during periods of financial turmoil. However, the results in column (6) should be taken lightly, as the adjusted $\mathrm{R}^{2}$ drops by almost half compared to

\footnotetext{
${ }^{13}$ See Figure 2
} 
the other specification. While the adjusted $\mathrm{R}^{2}$ still indicates that our model is reasonably useful, it also suggests the large importance of the firm cluster-year fixed effects, which proxy for credit demand. Finally, in column (5), we present the results of the interaction between our bank-specific capital market index and the \# Trading Memberships $>2$ dummy. Neither the interaction nor the capital markets index are statistically significant. The index can proxy for a bank's exposure to price fluctuation in the securities in which the bank is actually investing. However, it seems that our index cannot capture this phenomenon well enough.

In summary, we find support for the hypothesis that banks with greater trading expertise provide fewer loans to non-financial borrowers and reduce credit supply specifically during financial crises. Both findings are consistent with the theoretical predictions of Diamond and Rajan (2011), Shleifer and Vishny (2010), and Boot and Ratnovski (2016).

\subsection{Real Effects}

In this section, we investigate whether the reduced credit supply of banks with greater trading expertise translates into lower capital expenditure or lower employment growth of their borrowers. We use model (2) to test this channel of spillover from the banking sector to the real economy. Table 6 shows the results for capital expenditure as the dependent variable. In columns (1) and (2), we consider a direct transmission channel of banks' securities trading to capital expenditure through lending. $\overline{\text { Trading Exposure }}_{t}$ measures the share of loans granted to a firm cluster from banks with more than two trading memberships, i.e., those with trading expertise, in year $t$. In column (1), we only include $\overline{\text { Trading Exposure }}_{t}$, while in column (2), we interact this measure with a 2007 to 2009 financial crisis dummy. ${ }^{14}$ The crisis dummy itself turns out to be positive and significant. While surprising at first, this can be explained by the delayed response of capital expenditure to the financial crisis, which cannot be captured by the dummy as it does not allow for distinction between crisis years. Figure 4 a) shows that capital expenditure continued to increase (albeit at a

\footnotetext{
${ }^{14}$ To be able to also include year fixed effects in this specification, we need to drop one additional year dummy.
} 


\section{Table 5: Trading Expertise and Bank Lending}

Notes: In this table, we present the results of a modified version of the Khwaja and Mian (2008) model. The unit of observation is firm cluster-bank-year. Firm clusters are formed based on a firm's country of incorporation, the two-digit SIC code, and a firm's credit rating, estimated based on the median EBIT interest coverage ratios. Trading Membership equals one if a bank has at least one trading membership at a major stock exchange and zero otherwise. \# Trading Memberships represents the number of a bank's trading memberships at major stock exchanges. \# Trading Memberships > 2 equals one if \# Trading Memberships is greater than two and zero otherwise. Capital Markets is the market capitalization weighted average over the change Standard \& Poors Global Equity Index for the countries in which a bank possesses a trading membership at the regional stock exchange and the bank's country of incorporation. Financial stress is the value of the Financial Stress Indicator as provided by the US OFR for a bank's country of incorporation. All regressions include bank-level controls (the logarithm of total assets, return-on-assets, common equity/total assets, cash/total assets, total loans/total deposits). Standard errors are clustered at the bank-firm cluster level. Significance levels: ${ }^{*} p<0.1 ;{ }^{* *} p<0.05 ;{ }^{* * *} p<0.01$.

\begin{tabular}{|c|c|c|c|c|c|c|}
\hline & \multicolumn{6}{|c|}{ Dependent variable: $\Delta \log ($ Loan Volume $)$} \\
\hline & (1) & (2) & (3) & (4) & $(5)$ & (6) \\
\hline Trading Membership & $\begin{array}{c}0.020 \\
(0.029)\end{array}$ & & & & & \\
\hline \# Trading Memberships & & $\begin{array}{l}-0.027^{* * *} \\
(0.004)\end{array}$ & & & & \\
\hline \# Trading Memberships $>2$ & & & $\begin{array}{c}-0.211^{* * *} \\
(0.027)\end{array}$ & $\begin{array}{l}-0.209^{* * *} \\
(0.027)\end{array}$ & $\begin{array}{c}-0.214^{* * *} \\
(0.027)\end{array}$ & $\begin{array}{c}-0.160^{* * *} \\
(0.026)\end{array}$ \\
\hline Financial Stress ${ }_{t}$ & & & & $\begin{array}{c}0.007 \\
(0.008)\end{array}$ & & \\
\hline Capital Markets ${ }_{t}$ & & & & & $\begin{array}{c}0.036 \\
(0.075)\end{array}$ & \\
\hline Crisis & & & & & & $\begin{array}{c}-0.220^{* * *} \\
(0.012)\end{array}$ \\
\hline (\# Trading Memberships $>2$ )*Financial Stress ${ }_{t}$ & & & & $\begin{array}{c}-0.033^{* * *} \\
(0.004)\end{array}$ & & \\
\hline (\# Trading Memberships $>2$ )*Capital Markets ${ }_{t}$ & & & & & $\begin{array}{c}0.021 \\
(0.045)\end{array}$ & \\
\hline (\# Trading Memberships $>2$ )*Crisis & & & & & & $\begin{array}{c}-0.256^{* * *} \\
(0.018)\end{array}$ \\
\hline Observations & 268,910 & 268,910 & 268,910 & 268,910 & 268,910 & 268,910 \\
\hline Adjusted $\mathrm{R}^{2}$ & 0.374 & 0.374 & 0.374 & 0.371 & 0.374 & 0.192 \\
\hline Bank Controls & YES & YES & YES & YES & YES & YES \\
\hline Firm Cluster-Year FE & YES & YES & YES & YES & YES & NO \\
\hline Bank Country-Year FE & YES & YES & YES & NO & YES & NO \\
\hline Firm Cluster FE & NO & NO & NO & NO & NO & YES \\
\hline Bank Country & NO & NO & NO & YES & NO & YES \\
\hline
\end{tabular}




\section{Figure 3: The Effect of Trading Expertise as a Function of Financial Stress}

Notes: In this figure, we show the marginal effect of the \# Trading Memberships $>2$ dummy for different levels of the Financial Stress Index published by the US OFR. The Financial Stress Index is centered on zero. The positive values of the index indicate financial market stress, and negative values indicate financial market relaxation (stabilizing conditions). See Figure 2 for a plot of the time series of the index. The axis below shows the observed index values during our sample period. During the 2007 to 2009 financial crisis, the index peaked, close to a value of 15, with an average across 2007 to 2009 of approximately 5.55. The effect is computed using the coefficients reported in column (4) of Table 5. The solid bold line represents the marginal effect, and the shaded area represents the corresponding $95 \%$ confidence interval using cluster robust standard errors.

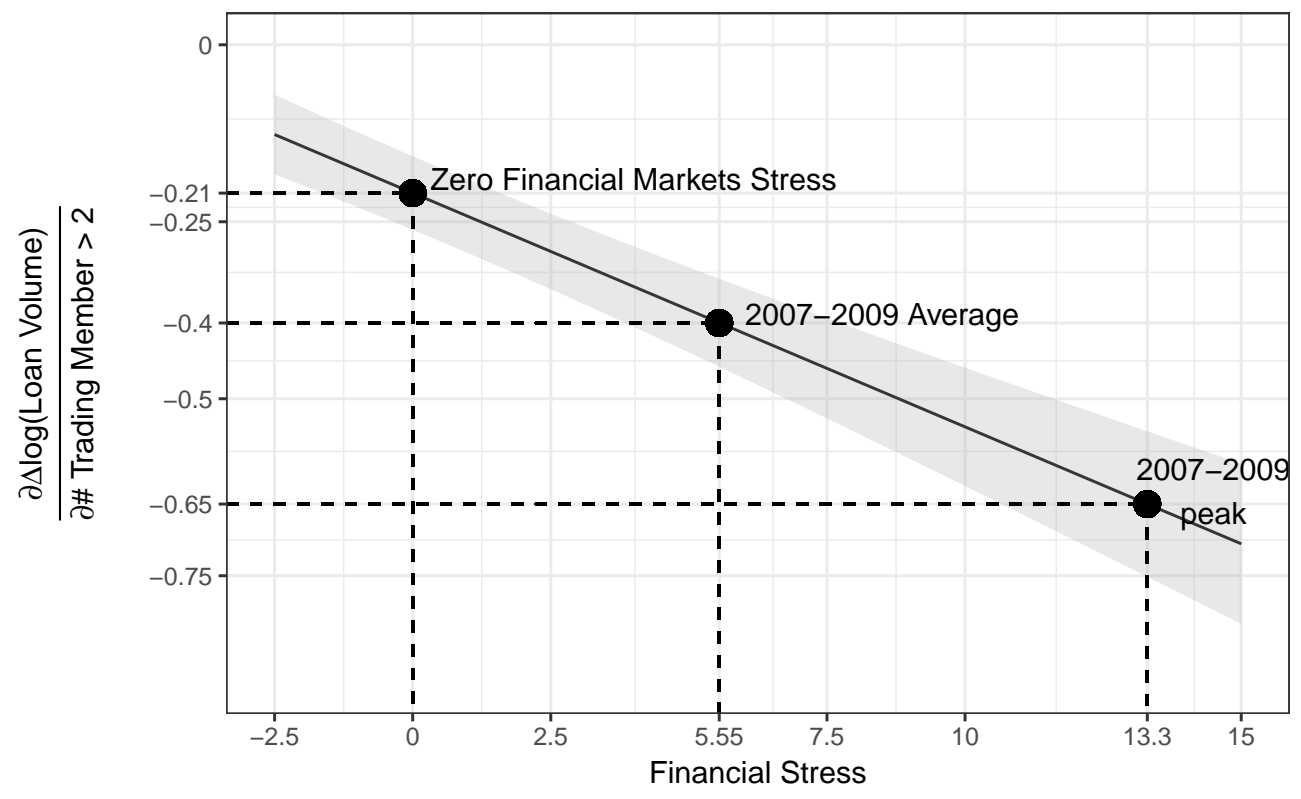


lower rate) at the onset of the financial crisis from 2007 to 2008. Only then did capital expenditure decline sharply, reaching its minimum in 2010 when the situation in the financial sector had already normalized. ${ }^{15}$ The interaction term in column (2) is statistically significant, indicating that there is a negative effect of exposure to banks with trading expertise during the financial crisis. In column (3), we repeat the model from column (2) but now use the Financial Stress Index instead of a simple crisis dummy to gain a more granular measurement of the impact of the crisis. Using the Financial Stress Index rather than a crisis dummy does not only allow us to distinguish between different crisis years, but also allows for the distinction of differences in the intensity of the financial crisis in different countries. The disadvantage of using the Financial Stress Index is its narrow focus on capital market conditions. Thus, the index does not capture all aspects of the crisis. The Financial Stress Index is negative and statistically significant and thus has the expected sign. However, the interaction term between the Financial Stress Index and $\overline{\text { Trading Exposure }}_{t}$ is insignificant. This does not necessarily contradict the results reported in column (2). While the crisis dummy in column (2) captures a globally uniform impact of the crisis, the Financial Stress Index here is specific to capital market stress in the firm cluster's country of incorporation. Thus, the insignificant interaction term merely implies that increased stress in a borrower's home country does not affect capital expenditure. Note that our firm clusters consist of rather large companies who are listed on stock exchanges. Smaller companies might be affected by local capital markets conditions to a greater extent.

Next, we investigate whether financial market stress in lender countries affects capital expenditure. In column (4), we include $\overline{\text { Bank FSI Exposure }}_{t}$, which is simply a weighted average of the values of the Financial Stress Indices of all lenders of a firm cluster, weighted by the respective share of the total loans this firm cluster received. Thus, we test whether there is a transmission of financial stress from banks to their borrowers unconditional on whether the banks have trading expertise or not. The coefficient associated with $\overline{\text { Bank FSI Exposure }}_{t}$ is statistically

\footnotetext{
${ }^{15}$ This behavior is consistent with the results reported in Kahle and Stulz (2013).
} 


\section{Figure 4: Capex and Employment Growth Development Over Time}

Notes: In panels a) and b) below, we present the time series of cross-sectional mean values of capital expenditure as a share of total assets and employment growth across regions and globally for firm clusters incorporated in the US, other advanced economies, and emerging economies as defined by the US Office of Financial Research. Employment growth at the firm cluster level is computed as the year-to-year change in the logarithm of the number of employees.

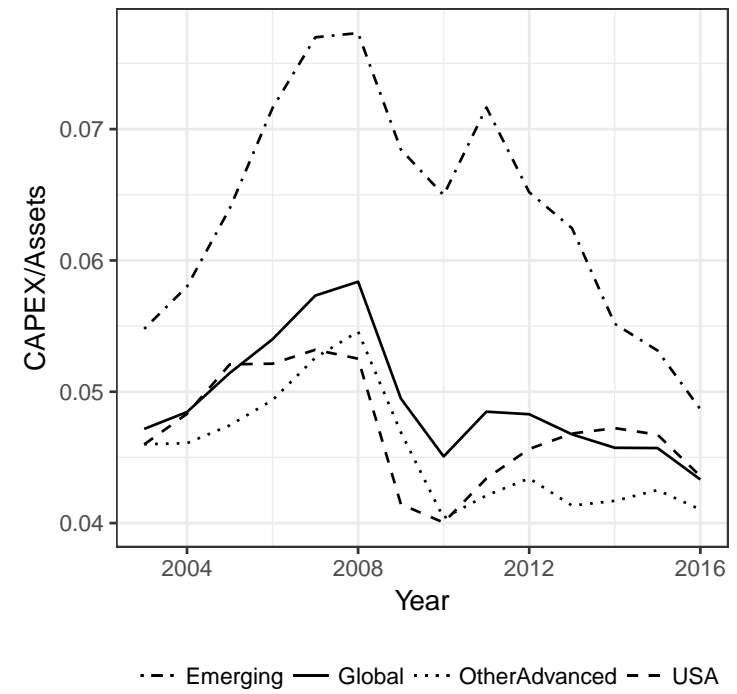

a) Capital Expenditure (Capex)

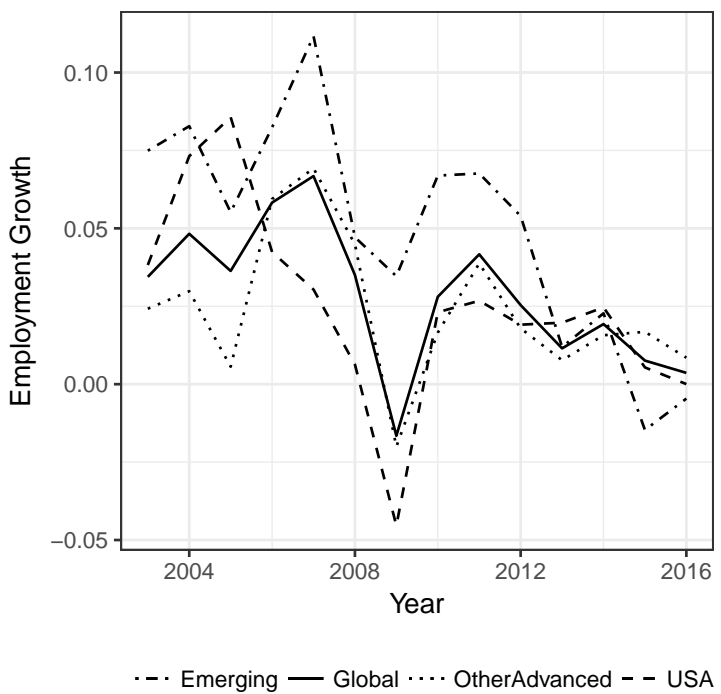

b) Employment Growth

insignificant, indicating no such effect. Finally, in column (5), we investigate whether there is a transmission of financial market stress to borrowers' capital expenditure by banks with trading expertise. We include $\overline{\text { Trading Bank FSI Exposure }}_{t}$, which has the same interpretation as $\overline{\text { Bank FSI Exposure }}_{t}$ but only takes banks with trading expertise into account. Now, the coefficient is statistically significant and negative, indicating that borrowers tend to reduce their capital expenditure if their dependence on banks with trading expertise increases and if these banks are experiencing financial stress in their home markets. The results concerning employment growth in Table 7 indicate that the effect of $\overline{\text { BankFSI Exposure }}_{t}$ is negative and highly statistically significant. Moreover, the coefficients of $\overline{\text { Trading Exposure }}_{t}$ and its interaction with our crisis dummy variable in column (2) are statistically insignificant. However, to get a better understanding of the effect of $\overline{\text { Trading Exposure }}_{t}$ during the 2007 to 2009, crisis we plot the marginal effect of the crisis dummy on employment growth in Figure 5. We plot the marginal effect of the crisis 


\section{Table 6: Does Trading or Crisis Exposure Affect Capex?}

Notes: In the table we present the results of the firm cluster level regressions. The unit of observation is firm cluster-year. The dependent variable is capital expenditure (Capex). The exposure measures are defined as in Equations (3) to (5). Crisis is a dummy variable equal to one for the years 2007 to 2009. If Crisis is included in the regression, the respective year fixed effects are dropped. FSI refers to the value Financial Stress Indicator, as developed by the US Office for Financial Research for the firm's country of incorporation. Bank FSI Exposure ${ }_{t}$ measures the firm's exposure to the FSI values of its lending banks, while Trading Bank FSI Exposure ${ }_{t}$ measures exposure to the FSI values of lending banks that also possess trading expertise. All regressions include country, industry, and year fixed effects and one-year lagged firm cluster control variables (the logarithm of total assets, net debt/total assets, intangible assets/total assets, $\triangle$ Cash/total assets, and EBITDA/total assets). Information on firm-bank lending relationships is taken from Thomson Reuter's LPC DealScan database. Firm data is obtained from Standard \& Poor's Compustat database. Our samples ranges from 2003 to 2016. All values are transformed to USD using the appropriate foreign exchange rates from Compustat. All standard errors are clustered at the firm cluster level. Significance levels: ${ }^{*} p<0.1 ;{ }^{* *} p<0.05 ;{ }^{* * *} p<0.01$.

\begin{tabular}{|c|c|c|c|c|c|}
\hline & \multicolumn{5}{|c|}{ Dependent Variable: Capex $/$ Total Assets ${ }_{t}$} \\
\hline & (1) & (2) & (3) & (4) & $(5)$ \\
\hline$\overline{\text { Trading Exposure }}_{t}$ & $\begin{array}{c}0.001 \\
(0.002)\end{array}$ & $\begin{array}{c}0.002 \\
(0.002)\end{array}$ & $\begin{array}{c}0.001 \\
(0.002)\end{array}$ & & \\
\hline Crisis & & $\begin{array}{c}0.006^{* * *} \\
(0.001)\end{array}$ & & & \\
\hline Financial Stress $_{t}$ & & & $\begin{array}{c}-0.001^{* * *} \\
(0.0004)\end{array}$ & $\begin{array}{c}-0.001^{* * *} \\
(0.0004)\end{array}$ & $\begin{array}{c}-0.001^{* * *} \\
(0.0004)\end{array}$ \\
\hline$\overline{\text { Trading Exposure }}_{t} *$ Crisis & & $\begin{array}{c}-0.003^{*} \\
(0.002)\end{array}$ & & & \\
\hline$\overline{\text { Trading Exposure }}_{t} *$ Financial Stress ${ }_{t}$ & & & $\begin{array}{c}-0.0003 \\
(0.0004)\end{array}$ & & \\
\hline$\overline{\text { Bank FSI Exposure }}_{t}$ & & & & $\begin{array}{c}-0.0002 \\
(0.001)\end{array}$ & \\
\hline$\overline{\text { Trading Bank FSI Exposure }}_{t}$ & & & & & $\begin{array}{l}-0.001^{*} \\
(0.0004) \\
\end{array}$ \\
\hline Observations & 17,768 & 17,768 & 17,768 & 17,768 & 17,768 \\
\hline Adjusted $\mathrm{R}^{2}$ & 0.385 & 0.386 & 0.386 & 0.386 & 0.386 \\
\hline Country FE & YES & YES & YES & YES & YES \\
\hline Industry FE & YES & YES & YES & YES & YES \\
\hline Year FE & YES & YES & YES & YES & YES \\
\hline Firm Cluster Controls & YES & YES & YES & YES & YES \\
\hline
\end{tabular}


dummy rather than the marginal effect of $\overline{\text { Trading Exposure }}_{t}$, since we have from Equation (2): $\partial$ Employment Growth $/ \partial$ Crisis $=\Psi_{\text {Crisis }}+\lambda \times \overline{\text { Trading Exposure }}$. Thus, we investigate the effect of the crisis on employment growth for the various levels of $\overline{\text { Trading Exposure }}_{t}$. The figure shows the negative and statistically significant effect of the crisis on employment growth that becomes stronger as $\overline{\text { Trading Exposure }}_{t}$ increases. However, the additional decrease in employment growth due to $\overline{\text { Trading Exposure }}_{t}$ is limited. While firms that do not borrow from banks with trading expertise reduce the number of employees by approximately $4.8 \%$, firms that obtain all of their borrowing from banks with trading expertise reduce the number of employees by approximately $5.5 \%$.

In summary, we find that dependency on banks with trading expertise does not only negatively affect borrowers investments in capital but also affects employment growth. 


\section{Figure 5: The Marginal Effect of Trading Exposure During a Crisis}

Notes: In this figure, we show the marginal effect of the 2007 to 2009 crisis dummy for different levels of the variable $\overline{\text { Trading Exposure }}_{t}$. The effect is computed using the coefficients reported in column (2) of Table 7, assuming that the crisis dummy is set to one. On the x-axis we show the range of values of $\overline{\text { Trading Exposure }}_{t}$ in our sample. The solid bold line represents the marginal effect. The shaded area represent the 95\% confidence interval around the marginal effect using cluster robust standard errors.

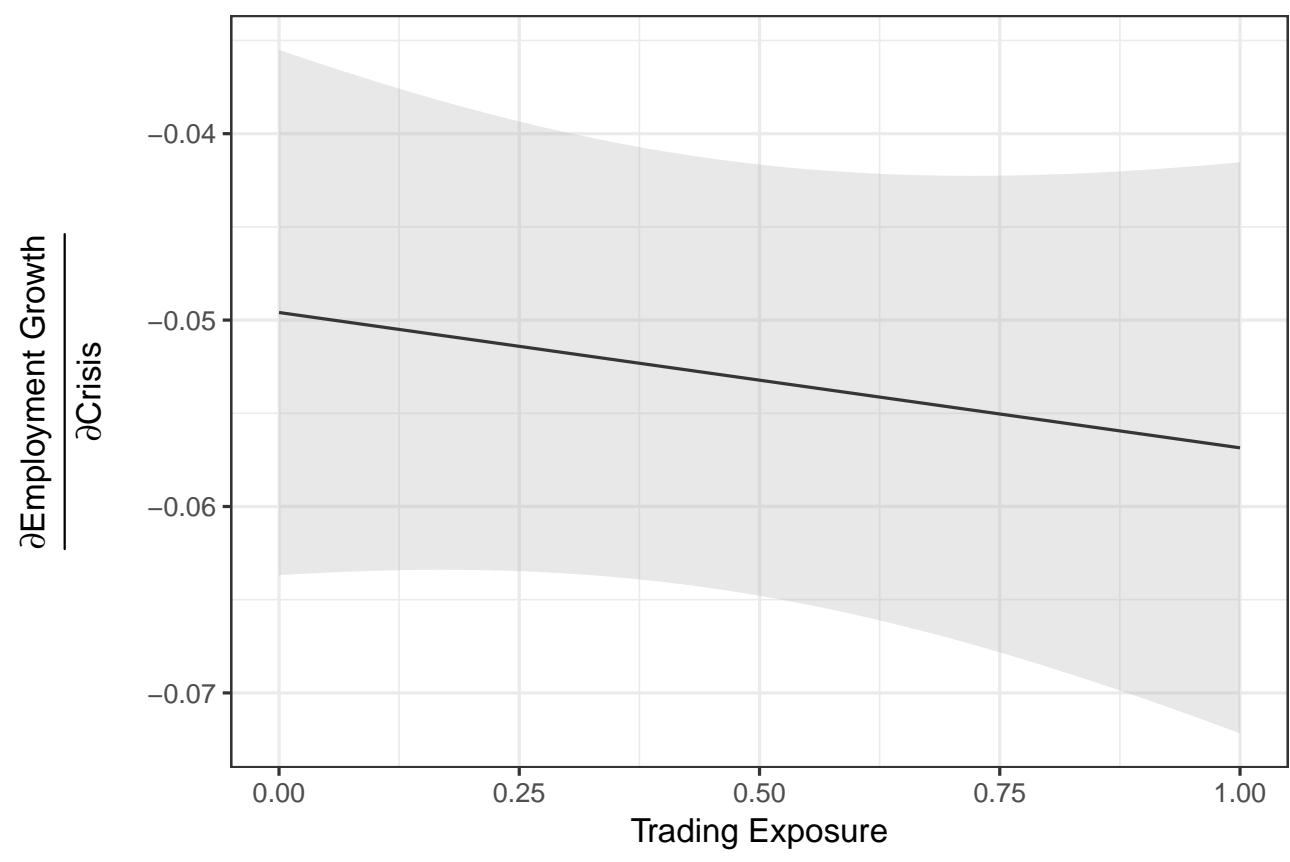




\section{Table 7: Are Trading or Crisis Exposure Affecting Employment Growth?}

Notes: In this table, we present the results of the firm cluster level regressions. The unit of observation is firm cluster-year. The dependent variable is employment growth, measured as the year-to-year change in the logarithm of the number of employees. The exposure measures are defined in Equations (3) to (5). Crisis is the dummy variable, equal to one for the years 2007 to 2009. If Crisis is included in the regression, the respective year fixed effects are dropped. FSI refers to the value Financial Stress Indicator, as developed by the US Office for Financial Research, for the firm's country of incorporation. $\overline{B a n k ~ F S I ~ E x p o s u r e ~}_{t}$ measures the firm's exposure to the FSI values of its lending banks, while Trading Bank FSI Exposure ${ }_{t}$ measures exposure to the FSI values of lending banks that also possess trading expertise. All regressions include country, industry, and year fixed effects and one year lagged firm cluster control variables (the logarithm of total assets, net debt/total assets, intangible assets/total assets, $\Delta$ Cash/total assets, and EBITDA/total assets). Information on firm-bank lending relationships is taken from Thomson Reuters LPC DealScan database. Firm data is obtained from Standard \& Poor's Compustat database. Our sample ranges from 2003 to 2016. All values are converted to USD using the appropriate foreign exchange rates from the Compustat database. All standard errors are clustered at the firm cluster level. Significance levels: ${ }^{*} p<0.1 ;{ }^{* *} p<0.05 ;{ }^{* * *} p<0.01$.

\begin{tabular}{|c|c|c|c|c|c|}
\hline & \multicolumn{5}{|c|}{ Dependent Variable: Employment Growth ${ }_{t}$} \\
\hline & (1) & (2) & (3) & (4) & (5) \\
\hline$\overline{\text { Trading Exposure }}_{t}$ & $\begin{array}{c}-0.012^{*} \\
(0.006)\end{array}$ & $\begin{array}{l}-0.009 \\
(0.007)\end{array}$ & $\begin{array}{c}-0.012^{*} \\
(0.006)\end{array}$ & & \\
\hline Crisis & & $\begin{array}{l}-0.005 \\
(0.007)\end{array}$ & & & \\
\hline Financial Stress ${ }_{t}$ & & & $\begin{array}{l}-0.001 \\
(0.002)\end{array}$ & $\begin{array}{c}0.001 \\
(0.002)\end{array}$ & $\begin{array}{l}-0.001 \\
(0.002)\end{array}$ \\
\hline$\overline{\text { Trading Exposure }}_{t} *$ Crisis & & $\begin{array}{l}-0.011 \\
(0.009)\end{array}$ & & & \\
\hline$\overline{\text { Bank FSI Exposure }}_{t}$ & & & & $\begin{array}{c}-0.008^{* * *} \\
(0.002)\end{array}$ & \\
\hline$\overline{\text { Trading Bank FSI Exposure }}_{t}$ & & & & & $\begin{array}{l}-0.001 \\
(0.002)\end{array}$ \\
\hline Observations & 17,768 & 17,768 & 17,768 & 17,768 & 17,768 \\
\hline Adjusted $\mathrm{R}^{2}$ & 0.060 & 0.060 & 0.060 & 0.061 & 0.060 \\
\hline Country FE & YES & YES & YES & YES & YES \\
\hline Industry FE & YES & YES & YES & YES & YES \\
\hline Year FE & YES & YES & YES & YES & YES \\
\hline Firm Cluster Controls & YES & YES & YES & YES & YES \\
\hline
\end{tabular}




\section{Further Analysis}

\subsection{Loan Pricing}

In this section, we present some additional results regarding the differences in loan pricing between banks with higher and lower trading expertise. Following the same approach as Acharya et al. (2018), we analyze loan pricing simply by adapting our Khwaja and Mian (2008) estimator in Equation (1) to the change in loan prices rather than the change in loan volume. Note that the Khwaja and Mian (2008) estimator and specifically the argument that the included borrower-year fixed effects can capture variations in unobserved credit demand is derived from a microeconomic model that relies on the loan volume. ${ }^{16}$ However, prices are also driven by demand. Thus, we believe that our empirical specification in Equation (1) remains valid if we use the change in loan prices as dependent variable.

We measure loan prices as All-in Spread drawn, which equals the total (fees and interest) annual spread paid over LIBOR drawn from the loan. In particular, we calculate All-in Spread drawn = Upfront fee + Annual fee + Utilization Fee + Interest Spread over LIBOR. Thus, the All-in Spread drawn represents the cost of financing for the relevant borrower (see, e.g., Ivashina (2005)).

We present the results of this analysis in Table 8. Our results indicate that all of our sample banks increase loan prices during periods of financial stress. Moreover, we find that banks with more trading expertise (measured either through \# Trading Memberships $>2$ or \# Trading Memberships) charge their borrowers higher prices for drawn loans. However, the interaction between the two effects is statistically insignificant. This indicates that while banks with more trading expertise generally tend to charge higher prices, they do not behave differently in terms of their loan pricing than banks without trading expertise during periods of crisis.

\footnotetext{
${ }^{16}$ See Khwaja and Mian (2008) for details regarding the derivation.
} 


\section{Table 8: The Effect of Trading on Loan Pricing}

Notes: In this table, we present the results regarding the effect of trading expertise on loan pricing. The unit of observation is firm cluster-year. The dependent variable is the change of the logarithm in the All-in Spread Drawn, while we calculate All-in Spread drawn = Upfront fee + Annual fee + Utilization Fee + Interest Spread over LIBOR. Firm clusters are formed based on a firm's country of incorporation, the two-digit SIC code, and a firm's credit rating, estimated based on the median EBIT interest coverage ratios. \# Trading Memberships represents the number of a bank's trading memberships at major stock exchanges. \# Trading Memberships > 2 equals one if \# Trading Memberships is greater than two and zero otherwise. Financial Stress is the value of the Financial Stress Indicator, as provided by the US OFR, for a bank's country of incorporation. All regressions include bank-level controls (the logarithm of total assets, return-on-assets, common equity/total assets, cash/total assets, and total loans/total deposits). Standard errors are clustered at the bank-firm cluster level. Significance levels: ${ }^{*} p<0.1 ;{ }^{* *} p<0.05 ;{ }^{* * *} p<0.01$.

Dependent Variable: $\Delta$ (All-in Spread Drawn)

(1)

\begin{tabular}{lcccc} 
\# Trading Memberships $>2$ & $0.757^{* * *}$ & \multicolumn{3}{c}{$0.781^{* * *}$} \\
& $(0.196)$ & & $(0.198)$ \\
\# Trading Memberships & & $0.088^{* * *}$ & & $0.092^{* * *}$ \\
& & $(0.026)$ & & $(0.027)$ \\
Financial Stress & $0.477^{* *}$ & $0.478^{* *}$ & $0.572^{* *}$ & $0.580^{* * *}$ \\
& $(0.212)$ & $(0.212)$ & $(0.226)$ & $(0.225)$ \\
\# Trading Memberships $>$ 2)*Financial Stress & & & -0.129 & \\
& & & $(0.125)$ & \\
(\# Trading Memberships)*Financial Stress & & & & -0.022 \\
& & & & $(0.019)$ \\
\hline Observations & 203,947 & 203,947 & 203,947 & 203,947 \\
Adjusted R ${ }^{2}$ & 0.266 & 0.266 & 0.266 & 0.266 \\
\hline Bank Controls & YES & YES & YES & YES \\
Firm Cluster-Year FE & YES & YES & YES & YES \\
Bank Country & YES & YES & YES & YES \\
\hline \hline
\end{tabular}




\subsection{Are US Banks Different?}

In our sample, the US is the most common country of origin of the banks. Thus, while we have a global sample, naturally, the question arises concerning to what extent our results are driven by US banks. In particular, these US banks include investment banking giants Goldman Sachs, Morgan Stanley, J.P. Morgan Chase, and Bank of America Merrill Lynch. We investigate whether there is a difference between US and non-US banks by repeating our analysis of model (1) for the US and non-US bank sub-samples. We show the results of this exercise in Table 9. Columns (1) and (2) present the results concerning the US sub-sample, while columns (3) and (4) present the results concerning the non-US sub-sample. A comparison of columns (1) and (3) shows that the trading expertise dummy \# Trading Memberships $>2$ is negative and statistically significant for US banks but not for non-US banks, while both coefficients are also statistically different from each other. This indicates that US banks with trading expertise indeed behave differently from non-US banks with trading expertise.

Next, a comparison of the interaction terms between trading expertise and financial stress in columns (2) and (4) shows that the interactions are negative and statistically significant in both sub-samples, while trading expertise in itself remains only significant in the US sub-sample. Furthermore, the levels of the coefficients associated with the Financial Stress Index and with the interaction term between the Financial Stress Index and \# Trading Memberships $>2$ differ between columns (2) and (4). Non-US banks without trading expertise reduce their credit supply by an approximate $4.3 \%$ per unit increase in the Financial Stress Index, while US banks without trading expertise reduce their credit supply by an approximate $11 \%$ per unit increase in the Financial Stress Index. Furthermore, non-US banks with trading expertise reduce their credit supply by an approximate $8 \%$ per unit increase in the Financial Stress Index, while we estimate that US banks with trading expertise reduce their credit supply by an approximate $13 \%$ per unit increase in the Financial Stress Index. These results demonstrate the great sensitivity of US banks to financial market stress, regardless of the banks' trading expertise. Comparing regression results across sub-samples can be 
Table 9: Are US Banks Different? - A Sub-Sample Analysis

Notes: In this table, we present the results regarding the effect of trading expertise on credit supply for the sub-samples that contain only US or non-US banks. The unit of observation is firm cluster-year. Firm clusters are formed based on a firm's country of incorporation, the two-digit SIC code, and a firm's credit rating, estimated based on median EBIT interest coverage ratios. \# Trading Memberships represents the number of a bank's trading memberships at major stock exchanges. \# Trading Memberships $>2$ equals one if \# Trading Memberships is greater than two and zero otherwise. Financial Stress is the value of the Financial Stress Indicator, as provided by the US OFR, for a bank's country of incorporation. All regressions include bank-level controls (the logarithm of total assets, return-on-assets, common equity/total assets, and total loans/total deposits). Standard errors are clustered at the bank-firm cluster level. Significance levels: ${ }^{*} p<0.1 ;{ }^{* *} p<0.05 ;{ }^{* * *} p<0.01$.

\begin{tabular}{lcccc}
\hline \hline & \multicolumn{3}{c}{ Dependent Variable: $\Delta l o g($ Loan Volume $)$} \\
\cline { 2 - 5 } & \multicolumn{2}{c}{ US Banks } & \multicolumn{2}{c}{ non-US Banks } \\
& $(1)$ & $(2)$ & $(3)$ & $(4)$ \\
\hline \# Trading Memberships $>2$ & $-0.431^{* * *}$ & $-0.529^{* * *}$ & 0.019 & 0.021 \\
& $(0.047)$ & $(0.044)$ & $(0.031)$ & $(0.030)$ \\
Financial Stress & & $-0.117^{* * *}$ & & $-0.044^{* * *}$ \\
& & $(0.006)$ & & $(0.008)$ \\
\# Trading Memberships $>$ 2)*Financial Stress & & $-0.022^{* *}$ & & $-0.037^{* * *}$ \\
& & $(0.009)$ & & $(0.004)$ \\
\hline Observations & & & & \\
Adjusted R ${ }^{2}$ & 66,065 & 66,065 & 202,845 & 202,845 \\
Bank Controls & 0.407 & 0.272 & 0.384 & 0.379 \\
Firm Cluster-Year FE & YES & YES & YES & YES \\
Bank Country-Year FE & YES & YES & YES & YES \\
Bank Country & YES & NO & YES & NO \\
Year FE & NO & NO & NO & YES \\
\hline \hline
\end{tabular}


problematic. Therefore, we also re-estimate our (1) but include a dummy variable that equals one for banks headquartered in the US and zero otherwise. We interact this US banks dummy with all variables in (1). To account for differences in regulatory and macroeconomic environments among countries, we further augment the model with a set of bank country dummy variables for countries other than the US. ${ }^{17}$ This allows us to estimate different slope coefficients for US and non-US bank with in a single regression equation. We show the results of this exercise in Table 10. The first three rows (1. - 3.) in the table show the estimated coefficients if the US banks dummy equals zero, while the next three rows (4. - 6.) show the estimated coefficients if the US banks dummy equals one. To assess the statistical significance of the difference in the coefficients we also perform a Wald test for the null hypothesis that the coefficients for US and non-US banks are equal. Thus, we test $\left.H_{0}: 1.\right)=4$.) and $\left.H_{0}: 1.\right)=4$.) and 3.) =6.) for columns (1) and (2) respectively. The corresponding test statistic is reported at the bottom of the table.

Consistent with our sub-sample analysis, the hypothesis of the equal slope coefficients of US and non-US banks is clearly not supported. While the results of the sub-sample analysis remain unchanged qualitatively, the magnitude of the difference in the coefficients between US and non-US banks becomes larger. To visualize the difference in the behavior of US and non-US banks, we plot the marginal effect of \# Trading Memberships $>2$ for US and non-US banks in Figure 6. If Financial Stress is zero, non-US banks tend not to change their credit supply, while there is a pronounced negative effect for US banks corresponding to a reduction in credit supply of approximately $45 \%$. As the value of the Financial Stress Index increases, the effect of trading expertise on credit supply increases for both US and non-US banks. However, the total reduction in the credit supply of US banks remains significantly higher as the total reduction in credit supply of non-US banks. In summary, this analysis suggests that our previous results for economically stable times are driven by the behavior of US banks, i.e., it is mainly US banks with trading expertise who cut their credit

\footnotetext{
${ }^{17}$ In other words, we include a full set of bank country dummy variables, but we only interact the US banks dummy with the other covariates.
} 


\section{Table 10: Are US Banks Different? - Single Equation}

Notes: In this table, we present the results regarding the effect of trading expertise on credit supply for US or non-US banks. Instead of splitting the sample, we introduce a US banks dummy variable and interact it with the \# Trading Memberships > 2 dummy, the Financial Stress Index, and all bank-level controls. The upper part of the table shows the estimated coefficients if the US banks dummy equals zero, and the lower part shows the estimated coefficients if the US banks dummy equals one. The unit of observation is firm cluster-year. Firm clusters are formed based on a firm's country of incorporation, the two-digit SIC code, and a firm's credit rating, estimated based on the median EBIT interest coverage ratios. \# Trading Memberships represents the number of a bank's trading memberships at major stock exchanges. \# Trading Memberships $>2$ equals one if \# Trading Memberships is greater than two and zero otherwise. Financial Stress is the value of the Financial Stress Indicator, as provided by the US OFR, for a bank's country of incorporation. All regressions include bank-level controls (the logarithm of total assets, return-on-assets, common equity/total assets, and total loans/total deposits). The Wald statistic corresponds to a test of $\left.H_{0}: 1.\right)=4$.) and $\left.H_{0}: 1.\right)=4$.) and 3.) =6.) for columns (1) and (2) respectively. Standard errors are clustered at the bank-firm cluster level. Significance levels: ${ }^{*} p<0.1 ;{ }^{* *} p<0.05 ;{ }^{* *} p<0.01$.

Dependent Variable: $\Delta \log ($ Loan Volume)

US Banks Dummy $=0$

1.) \# Trading Memberships $>2$

0.035

(0.031)

$(0.031)$

2.) Financial Stress

$-0.015^{*}$

$(0.008)$

3.) (\# Trading Memberships $>2$ )*Financial Stress

$-0.037^{* * *}$

(0.004)

US Banks Dummy = 1

4.) \# Trading Memberships $>2$

$-0.596^{* * *}$

(0.060)

$-0.601^{* * *}$

5.) Financial Stress

(0.060)

$-0.017^{* *}$

$(0.007)$

6.) (\# Trading Memberships > 2)*Financial Stress

$-0.003$

(0.009)

\begin{tabular}{lcc}
\hline Wald Statistic & $\begin{array}{c}121.455 \\
(\mathrm{df}=1)\end{array}$ & $\begin{array}{c}123.598 \\
(\mathrm{df}=2)\end{array}$ \\
\hline Observations & 268,910 & 268,910 \\
Adjusted R & 0.372 & 0.373 \\
\hline Bank Controls & YES & YES \\
Firm Cluster-Year FE & YES & YES \\
Non-US Bank Country Dummies & YES & YES \\
\hline \hline
\end{tabular}


Figure 6: The Marginal Effect of Trading Expertise - A Single Equation

Notes: In this figure, we present the marginal effect of Trading Expertise for different levels of the Financial Stress Index. The effects are based on the regression specification reported in column (2) in Table 10, setting the \# Trading Memberships $>2$ dummy equal to one. The dashed line shows the marginal effect if the US banks dummy equals zero, while the solid line shows the marginal effect if the US banks dummy equals one. The shaded areas represent the $95 \%$ confidence intervals around the marginal effects using cluster robust standard errors.

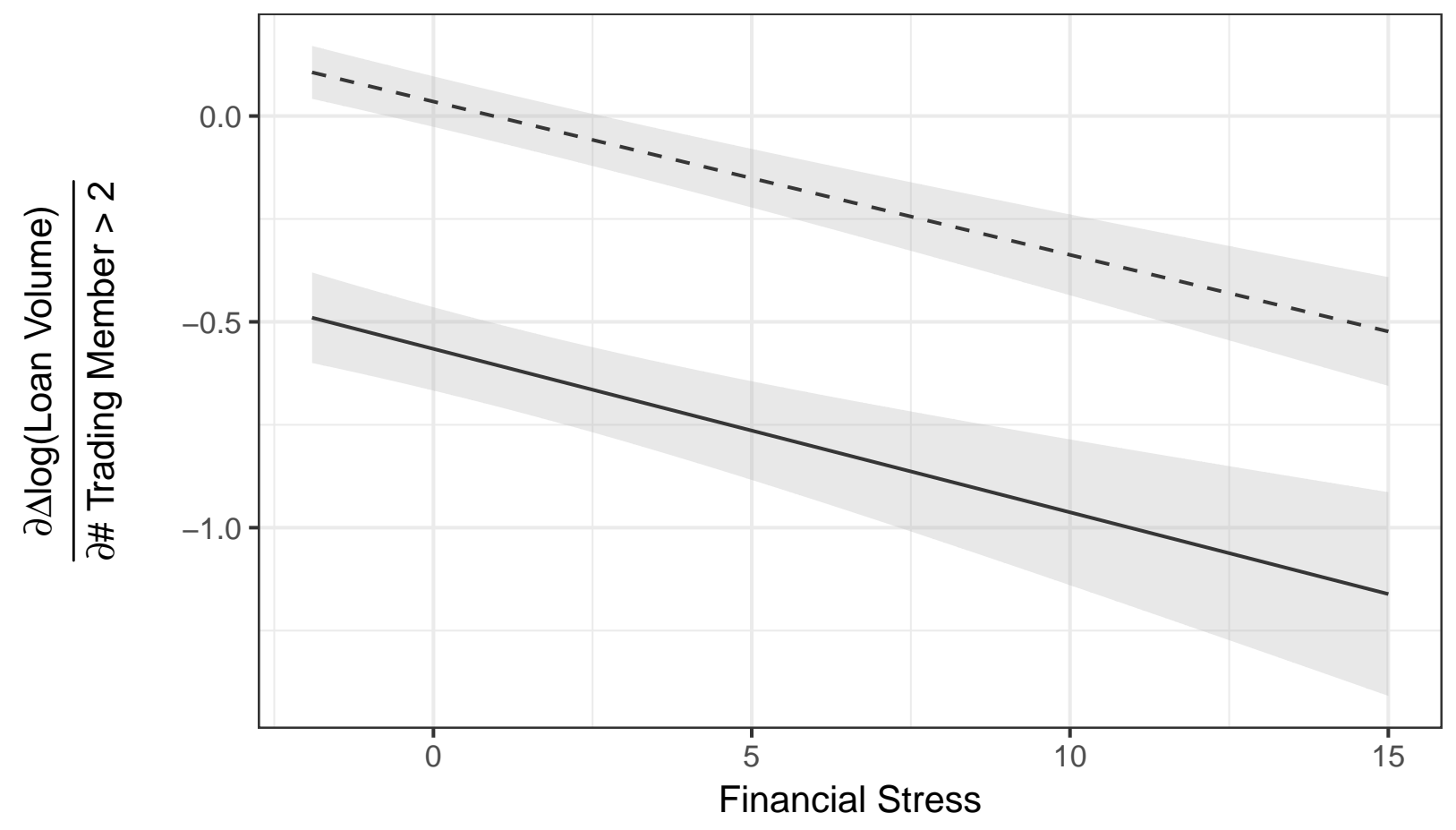

- - U.S. Banks Dummy = 0 - U.S. Banks Dummy = 1 
supply during stable economic times, and they cut their credit supply even further during periods of crisis. However, non-US banks with trading expertise do not reduce their credit supply during economically stable times. They do so during crises. Thus, the behavior of non-US banks is on the one hand consistent with the theoretical prediction that banks with trading expertise reduce their credit supply during crisis to be able to invest in assets for fire-sale prices (see, e.g., Diamond and Rajan (2011), Shleifer and Vishny (2010)). On the other hand, we do not see evidence for the theoretical prediction that non-US banks also reduce their credit supply in economically stable times to allocate funds to (scalable and rather short-term) trading instead of relationship banking activities, such as lending (see Boot and Ratnovski (2016)). However, for US banks, both channels apply, as US banks with trading expertise reduce their credit supply both in times of crises and in periods of stability.

This difference in behavior between US and non-US banks is important in the assessment of differences in the regulatory regimes regarding proprietary trading by banks in the US and e.g. the UK or the EU. The U.S. Volcker Rule goes further than its UK or EU equivalents as it bans banks from engaging in proprietary trading, while UK and EU regulations only force an insulation of banking activities from trading losses within a banking group without actually banning proprietary trading.

\subsection{Trading Expertise and Foreign Lending}

Home biases in lending and a general decline in foreign lending are well documented in the literature (see, e.g., Marchetti (2016)). In this section, we aim to contribute to this literature by analyzing the effect of banks' trading expertise on foreign lending, and we define foreign lending as loans granted by a bank to a borrower that is incorporated in a country other than the bank. ${ }^{18}$ Thus, we create a new variable that equals one if a bank's and borrower's country of incorporation differ and zero otherwise.

\footnotetext{
${ }^{18}$ In the case of syndicated loans, i.e., loans that are granted by multiple banks forming a syndicate, the loan is classified as foreign lending if at least one bank is incorporated in another country.
} 
To gain further insight, we also create measures of the geographic and economic distance between a bank's and borrower's country of incorporation. We compute the geographic distance between the bank and borrower countries using the great-circle distance formula used in physics and navigation. The great-circle distance is the shortest distance between any two points on the surface of a sphere and is computed as

$$
\operatorname{Distance}_{i, j}=r \times \arccos \left(\sin \left(\operatorname{Lat}_{i}\right) \sin \left(\operatorname{Lat}_{j}\right)+\cos \left(\operatorname{Lat}_{i}\right) \cos \left(\operatorname{Lat}_{j}\right) \cos \left(\operatorname{Long}_{i}-\operatorname{Long}_{j}\right)\right)
$$

where $L a t_{i}, L a t_{j}$ and $L o n g_{i}, L o n g_{j}$ are the latitude and longitude respectively, of the centroids of the bank country $i$ and borrower country $j .{ }^{19} r$ is Earth's mean radius in $\mathrm{km}(\approx 6,371 \mathrm{~km})$. Since Distance $_{i, j}$ is heavily skewed, we use the logarithm of Distance $_{i, j}$ in all regressions. If bank and borrower are incorporated in the same country, we set Distance $_{i, j}=1$ instead of using the greatcircle distance. ${ }^{20}$ Thus, the logarithm of the geographic distance equals zero whenever the foreign lending dummy equals zero.

We proxy for the economic distance between bank and borrower countries using the absolute value of the difference in the KOF Globalisation Index. ${ }^{21}$ The index is a measure of the level of globalization of individual countries along economic, social, and political dimensions. ${ }^{22}$

We repeat our estimation of our model (1) but augment the regression model with the foreign lending dummy, the geographic distance measure, and the economic distance measure. In columns (1) and (2) of Table 12, we show the results for the foreign lending dummy. The coefficient associated with foreign lending is negative and statistically significant, indicating a rather strong lending

\footnotetext{
${ }^{19}$ The centroid of a country is the geometric center of the two-dimensional polygon spanned by the country's borders.

${ }^{20}$ This approach simply implies that we assume that the physical distance in $\mathrm{km}$ between bank and borrower is $1 \mathrm{~km}$ if both are incorporated in the same country.

${ }^{21}$ The KOF Index is computed and published by the Swiss Economic Institute at ETH Zürich.

${ }^{22}$ For details regarding the computation of the index, see Dreher (2006) (the original version of the index) and Gygli, Haelg and Sturm (2018) (the revised version of the index which is used in this paper). Since the most current KOF Globalisation Index is only available until the year 2015, we augment the values for 2016 for each country using simple $\mathrm{AR}(\mathrm{p})$ one-year ahead forecasts, while for each country's time-series, the lag-length $\mathrm{p}$ is selected to minimize the AIC. Using data until 2015 does not change the results.
} 
home bias among the banks in our sample. The coefficient of interest in this regression specification is the interaction between our trading expertise measure \# Trading Memberships $>2$ and the foreign lending dummy. The interaction term coefficients are positive and statistically significant. Thus, banks with trading expertise tend to increase their credit supply to foreign markets by $1.2 \%$ to $2.5 \%$ compared to banks without trading expertise. At the same time, consistent with our previous results, banks with trading expertise reduce credit supply to their home market by $30 \%$ to $32 \%$ compared to banks without trading expertise. This behavior changes as the level of financial stress in the banks' home country increases. During a crisis, the banks with trading expertise reduce their credit supply to foreign markets by about $16 \%$ compared to banks without trading expertise. ${ }^{23}$

In columns (3) and (4) of Table 12, we repeat the analysis but use the geographic distance between the bank and borrower countries instead of the foreign lending dummy, and in columns (5) and (6), we use the economic distance. ${ }^{24}$ In either case, the conclusions remain the same as for the foreign lending dummy. However, using the geographic distance or economic distance reveals that the effect of banks with trading expertise increasing their loan supply in foreign markets while reducing their credit supply in their home market becomes stronger as the distance between bank and borrower countries increases. This effect is more pronounced for the geographic distance than for the economic distance.

The increase in credit supply to foreign markets by banks with trading expertise may simply reflect a greater degree of internationalization and a stronger specialization in the lending business of banks with trading expertise compared to banks without trading expertise. Banks with global lending operations may specialize in providing trade credit to exporters from specific markets. For example, the Spanish bank Banco Santander, which we classify as a bank with trading expertise, has a specialization in providing trade credit to Peruvian export firms (see Paravisini, Rappoport

\footnotetext{
${ }^{23}$ This position assumes a level of Financial Stress Index that is equal to 5.55, which corresponds to the average level of financial stress in advanced economies during the 2007 to 2009 financial crisis.

${ }^{24}$ In columns (5) and (6) of Table 12, the sample size is smaller than in the other regressions as the KOF Globalisation Index is not available for some of the countries in our sample. For example, while we observe banks and borrowers from Taiwan (rather counting them as part of China), there is no KOF Globalisation Index published for Taiwan.
} 
and Schnabl (2015)). De Haas and Van Horen (2012) show that banks generally reduce their credit supply to geographically distant locations. This is consistent with the negative coefficients associated with $\log ($ Distance) and Economic Distance in columns (3) and (4) in Table 12. However, De Haas and Van Horen (2012) also show that this effect is counteracted if banks operate foreign subsidiaries or foreign branches or have lending experience in a foreign market. Thus, the positive sign of the interactions between \# Trading Memberships $>2$ and $\log$ (Distance) or Economic Distance may simply reflect a geographically more dispersed branch network of banks with trading expertise compared to banks without trading expertise. Unfortunately, our data does not allow us to directly observe the branch network of the banks in our sample. However, LPC DealScan does report some branch information for loans in our sample as an addition to the lender name. For example, for some loans granted by BNP Paribas, DealScan reports "BNP Paribas Singapore Branch" as the lender name. Thus, for each loan in our sample for which we have some indication of the specific branch that granted the loan, we hand-collect the branch country and use the great-circle distance formula to compute the geographic distance between the branch country and the borrower country. ${ }^{25}$ While this is a rather imprecise measure of a bank's branch network, it may provide us with some general insight regarding the degree of geographic dispersion of a bank's lending business. We report the average distances between the bank country and the borrower country on the one hand and the bank branch country and the borrower country on the other hand in Table 11. We indeed find that for banks with trading expertise, the average geographic distance between the bank countries and borrower countries is larger than the average geographic distance between the bank branch countries and borrower countries. Additionally, we find that the average geographic distance between the bank branch countries and borrower countries is lower for banks with trading expertise than for banks without trading expertise. Both indicate a greater geographic dispersion of the lending operations and thus a higher degree of internationalization of banks with trading exper-

\footnotetext{
${ }^{25}$ Note that in many cases, the bank country, branch country, and borrower country are different. For example, we observe loans granted by BNP Paribas to borrowers in Malaysia or the Philippines via the Singapore Branch of BNP Paribas.
} 
Table 11: Do Trading Banks Have Geographically More Dispersed Lending Operations Than Non-Trading Banks?

Notes: In this table, we report the average geographic distance between bank country and borrower country for banks with trading expertise and without trading expertise. \# Trading Memberships $>2$ indicates banks with more than two trading memberships at securities exchanges and thus indicates trading expertise. \# Trading Memberships $\leq 2$ indicates the opposite. Avg. Distance Bank is the mean value of the logarithm of the geographic distance between the bank country and the borrower country. Avg. Distance Branch is the mean value of the logarithm of the geographic distance between the bank branch country and the borrower country. We report significance levels for two-sided t-tests of the mean difference, allowing for unequal sample variance as: ${ }^{*} p<0.1 ;{ }^{* *} p<0.05 ;{ }^{* * *} p<0.01$.

\begin{tabular}{llll}
\hline \hline & \# Trading Memberships $>2$ & \# Trading Memberships $\leq 2$ & Difference \\
\hline Avg. Distance Bank & 4.813 & 4.027 & $0.786^{* * *}$ \\
Avg. Distance Branch & 3.271 & 3.546 & $-0.274^{* * *}$ \\
\hline Difference & $1.541^{* * *}$ & $0.481^{* * *}$ & \\
\hline \hline
\end{tabular}

tise compared to banks without trading expertise. Hence, consistent with the results in De Haas and Van Horen (2012), the increased credit supply of banks with trading expertise to foreign markets seems to be driven by the greater geographic dispersion of the lending operations of these banks compared to banks without trading expertise. Approximately $65.6 \%$ of all bank-borrower loan connections in our sample can be described as foreign lending. However, many of these loans are granted within the EEA. ${ }^{26}$ However, common regulatory frameworks in many areas and an overall comparatively high degree of economic integration lead to a lower risk of foreign lending for EEA banks to EEA borrowers. For example, it is significantly easier to enforce contracts across borders within the EEA compared to the borders of other countries. Furthermore, there is a comparatively high degree of harmonization of regulations within the EEA. Thus, the EEA might be seen as a single lending market. If we treat the EEA as if it were one country in our definition of foreign lending, the share of bank-borrower loan connections that imply foreign lending is approximately 49.8\%. We repeat our analysis of the connection of trading expertise and foreign lending, treating the EEA as a single country, and report the results of this exercise in Table 13. While the magnitude of some coefficients change, the conclusions remain the same as in our previous analysis.

\footnotetext{
${ }^{26}$ The EEA essentially covers the EU plus Switzerland and Norway.
} 


\section{Table 12: Is Foreign Lending Affected Differently Than Domestic Lending by Trading Expertise?}

Notes: In this table, we present the results regarding the effect of trading expertise on credit supply in foreign lending. The unit of observation is firm cluster-year. Firm clusters are formed based on a firm's country of incorporation, the two-digit SIC code, and a firm's credit rating, estimated based on the median EBIT interest coverage ratios. \# Trading Memberships represents the number of a bank's trading memberships at major stock exchanges. \# Trading Memberships $>2$ equals one if \# Trading Memberships is greater than two and zero otherwise. Financial Stress is the value of Financial Stress Indicator, as provided by the US OFR, for a bank's country of incorporation. All regressions include bank-level controls (the logarithm of total assets, return-on-assets, common equity/total assets, cash/total assets, and total loans/total deposits). Foreign lending is a dummy variable that equals one if a bank's and borrower's country of incorporation are not the same. Distance is the physical distance between a bank's and borrower's country of incorporation. Economic distance is the absolute value of the difference in the KOF Globalisation Index of a bank's and borrower's country of incorporation. Standard errors are clustered at the bank-firm cluster level. Significance levels: ${ }^{*} p<0.1 ;{ }^{* *} p<0.05 ;{ }^{* * *} p<0.01$.

\begin{tabular}{|c|c|c|c|c|c|c|}
\hline & \multicolumn{6}{|c|}{ Dependent Variable: $\Delta \log ($ Loan Volume $)$} \\
\hline & (1) & (2) & (3) & (4) & (5) & (6) \\
\hline \# Trading Memberships $>2$ & $\begin{array}{c}-0.391^{* * *} \\
(0.040)\end{array}$ & $\begin{array}{c}-0.366^{* * *} \\
(0.040)\end{array}$ & $\begin{array}{c}-0.365^{* * *} \\
(0.040)\end{array}$ & $\begin{array}{c}-0.338^{* * *} \\
(0.040)\end{array}$ & $\begin{array}{c}-0.256^{* * *} \\
(0.031)\end{array}$ & $\begin{array}{c}-0.244^{* * *} \\
(0.030)\end{array}$ \\
\hline Foreign lending & $\begin{array}{c}-1.501^{* * *} \\
(0.032)\end{array}$ & $\begin{array}{c}-1.491^{* * *} \\
(0.032)\end{array}$ & & & & \\
\hline $\log ($ Distance $)$ & & & $\begin{array}{c}-0.177^{* * *} \\
(0.004)\end{array}$ & $\begin{array}{c}-0.176^{* * *} \\
(0.004)\end{array}$ & & \\
\hline Economic Distance & & & & & $\begin{array}{c}-0.063^{* * *} \\
(0.002)\end{array}$ & $\begin{array}{c}-0.062^{* * *} \\
(0.002)\end{array}$ \\
\hline Financial Stress & & $\begin{array}{c}-0.025^{* * *} \\
(0.009)\end{array}$ & & $\begin{array}{c}-0.028^{* * *} \\
(0.009)\end{array}$ & & $\begin{array}{c}0.002 \\
(0.009)\end{array}$ \\
\hline (\# Trading Memberships $>2$ )*Foreign Lending & $\begin{array}{c}0.420^{* * *} \\
(0.041)\end{array}$ & $\begin{array}{c}0.404^{* * *} \\
(0.041)\end{array}$ & & & & \\
\hline Foreign Lending*Financial Stress & & $\begin{array}{c}0.021^{* * *} \\
(0.006)\end{array}$ & & & & \\
\hline (\# Trading Memberships > 2)*Financial Stress & & $\begin{array}{c}-0.051^{* * *} \\
(0.007)\end{array}$ & & $\begin{array}{c}-0.051^{* * *} \\
(0.007)\end{array}$ & & $\begin{array}{c}-0.039^{* * *} \\
(0.005)\end{array}$ \\
\hline (\# Trading Memberships > 2)* $\log ($ Distance $)$ & & & $\begin{array}{c}0.046^{* * *} \\
(0.005)\end{array}$ & $\begin{array}{c}0.044^{* * *} \\
(0.005)\end{array}$ & & \\
\hline $\log (\text { Distance })^{*}$ Financial Stress & & & & $\begin{array}{c}0.003^{* * *} \\
(0.001)\end{array}$ & & \\
\hline (\# Trading Memberships $>2$ )*Economic Distance & & & & & $\begin{array}{c}0.010^{* * *} \\
(0.002)\end{array}$ & $\begin{array}{c}0.010^{* * *} \\
(0.002)\end{array}$ \\
\hline Economic Distance*Financial Stress & & & & & & $\begin{array}{c}-0.0004 \\
(0.001)\end{array}$ \\
\hline (\# Trading Memberships > 2)*Foreign Lending*Financial Stress & & $\begin{array}{c}0.012 \\
(0.009)\end{array}$ & & & & \\
\hline (\# Trading Memberships $>2)^{*} \log (\text { Distance })^{*}$ Financial Stress & & & & $\begin{array}{c}0.002 \\
(0.001)\end{array}$ & & \\
\hline (\# Trading Memberships $>2$ )*Economic Distance*Financial Stress & & & & & & $\begin{array}{c}0.001 \\
(0.001)\end{array}$ \\
\hline Observations & 268,910 & 268,910 & 268,910 & 268,910 & 266,317 & 266,317 \\
\hline Adjusted $\mathrm{R}^{2}$ & 0.413 & 0.409 & 0.416 & 0.412 & 0.386 & 0.382 \\
\hline Bank Controls & YES & YES & YES & YES & YES & YES \\
\hline Firm Cluster-Year FE & YES & YES & YES & YES & YES & YES \\
\hline Bank Country-Year FE & YES & NO & YES & NO & YES & NO \\
\hline Bank Country & NO & YES & NO & YES & NO & YES \\
\hline
\end{tabular}




\section{Table 13: Is Foreign Lending Affected Differently Than Domestic Lending by Trading Expertise? - EEA}

Notes: In this table, we present the results regarding the effect of trading expertise on credit supply in foreign lending, treating countries in the EEA as one country. The unit of observation is firm cluster-year. Firm clusters are formed based on a firm's country of incorporation, the two-digit SIC code, and a firm's credit rating estimated based on the median EBIT interest coverage ratios. \# Trading Memberships represents the number of a banks trading memberships at major stock exchanges. \# Trading Memberships $>2$ equals one if \# Trading Memberships is greater than two and zero otherwise. Financial Stress is the value of the Financial Stress Indicator, as provided by the U.S. OFR, for a bank's country of incorporation. All regressions include bank-level controls .(the logarithm of total assets, return-on-assets, common equity/total assets, cash/total assets, and total loans/total deposits). Foreign lending is a dummy variable that equals one if a banks and borrowers countries of incorporation are not the same. Distance is the physical distance between a banks and borrowers country of incorporation. Economic distance is the absolute value of the difference in the KOF Index of Globalization of a banks and borrowers country of incorporation. Standard errors are clustered at the bank-firm cluster level. Significance levels: ${ }^{*} p<0.1 ;{ }^{* *} p<0.05 ;{ }^{* * *} p<0.01$.

\begin{tabular}{|c|c|c|c|c|c|c|}
\hline & \multicolumn{6}{|c|}{ Dependent Variable: $\Delta \log ($ Loan Volume $)$} \\
\hline & (1) & (2) & (3) & (4) & (5) & (6) \\
\hline \# Trading Memberships $>2$ & $\begin{array}{c}-0.415^{* * *} \\
(0.034)\end{array}$ & $\begin{array}{c}-0.390^{* * *} \\
(0.034)\end{array}$ & $\begin{array}{c}-0.432^{* * *} \\
(0.034)\end{array}$ & $\begin{array}{l}-0.408^{* * *} \\
(0.034)\end{array}$ & $\begin{array}{c}-0.255^{* * *} \\
(0.030)\end{array}$ & $\begin{aligned}-0.244^{* * *} \\
\\
(0.029)\end{aligned}$ \\
\hline Foreign Lending & $\begin{array}{c}-1.288^{* * *} \\
(0.031)\end{array}$ & $\begin{array}{l}-1.278^{* * *} \\
(0.031)\end{array}$ & & & & \\
\hline $\log ($ Distance $)$ & & & $\begin{array}{c}-0.150^{* * *} \\
(0.004)\end{array}$ & $\begin{array}{l}-0.148^{* * *} \\
(0.003)\end{array}$ & & \\
\hline Economic Distance & & & & & $\begin{array}{c}-0.062^{* * *} \\
(0.002)\end{array}$ & $\begin{array}{c}-0.061^{* * *} \\
(0.002)\end{array}$ \\
\hline Financial Stress & & $\begin{array}{c}-0.021^{* *} \\
(0.009)\end{array}$ & & $\begin{array}{c}-0.023^{* *} \\
(0.009)\end{array}$ & & $\begin{array}{c}0.002 \\
(0.009)\end{array}$ \\
\hline (\# Trading Memberships $>2$ )*Foreign Lending & $\begin{array}{c}0.482^{* * *} \\
(0.038)\end{array}$ & $\begin{array}{c}0.462^{* * *} \\
(0.038)\end{array}$ & & & & \\
\hline Foreign lending*Financial Stress & & $\begin{array}{c}0.019^{* * *} \\
(0.006)\end{array}$ & & & & \\
\hline (\# Trading Memberships $>2$ )*Financial Stress & & $\begin{array}{c}-0.046^{* * *} \\
(0.006)\end{array}$ & & $\begin{array}{c}-0.043^{* * *} \\
(0.006)\end{array}$ & & $\begin{array}{c}-0.037^{* * *} \\
(0.005)\end{array}$ \\
\hline (\# Trading Memberships > 2)* $\log ($ Distance $)$ & & & $\begin{array}{c}0.060^{* * *} \\
(0.004)\end{array}$ & $\begin{array}{c}0.057^{* * *} \\
(0.004)\end{array}$ & & \\
\hline $\log (\text { Distance })^{*}$ Financial Stress & & & & $\begin{array}{c}0.003^{* * *} \\
(0.001)\end{array}$ & & \\
\hline (\# Trading Memberships > 2)*Economic Distance & & & & & $\begin{array}{c}0.010^{* * *} \\
(0.002)\end{array}$ & $\begin{array}{c}0.009^{* * *} \\
(0.002)\end{array}$ \\
\hline Economic Distance*Financial Stress & & & & & & $\begin{array}{l}-0.001 \\
(0.0005)\end{array}$ \\
\hline (\# Trading Memberships > 2)*Foreign Lending*Financial Stress & & $\begin{array}{l}0.015^{*} \\
(0.007)\end{array}$ & & & & \\
\hline (\# Trading Memberships $>2)^{*} \log (\text { Distance })^{*}$ Financial Stress & & & & $\begin{array}{c}0.001 \\
(0.001)\end{array}$ & & \\
\hline (\# Trading Memberships $>2$ )*Economic Distance*Financial Stress & & & & & & $\begin{array}{c}0.001 \\
(0.001)\end{array}$ \\
\hline Observations & 268,910 & 268,910 & 268,910 & 268,910 & 266,317 & 266,317 \\
\hline Adjusted $\mathrm{R}^{2}$ & 0.407 & 0.403 & 0.407 & 0.404 & 0.386 & 0.382 \\
\hline Bank Controls & YES & YES & YES & YES & YES & YES \\
\hline Firm Cluster-Year FE & YES & YES & YES & YES & YES & YES \\
\hline Bank Country-Year FE & YES & NO & YES & NO & YES & NO \\
\hline Bank Country & NO & YES & NO & YES & NO & YES \\
\hline
\end{tabular}




\section{Conclusion \& Policy Implications}

Do banks that heavily engage in proprietary trading reduce credit supply in times of crisis more than their peers that are less heavily engaged in proprietary trading? In our analysis, we answer this question using a global dataset containing information on loans granted by 136 leading banks to a wide range of corporate borrowers between 2003 and 2016. We find that banks with greater trading expertise supply less credit than their peers with lower trading expertise during stable times and even less during crisis times. Compared to non-trading banks, trading banks reduce their credit supply by $19 \%$ plus an additional $3.25 \%$ during crises. Both effects are consistent with theoretical predictions (see Shleifer and Vishny (2010), Diamond and Rajan (2011), Boot and Ratnovski (2016)) and are in line with previous empirical evidence derived from a one-country sample (see Abbassi et al. (2016)). Additionally, we demonstrate that banks engaged in trading also charge higher prices for their loans. Moreover, we show that the global dimension of our analysis is significant. The double effect of trading banks reducing credit supply during periods of crisis and stability can be attributed to US banks. International banks are unique in this regard, as they only reduce their credit supply during crises. From a theoretical point of view, this finding suggests that between US banks and international banks, there are two different channels at work, both leading to lower credit supply. The theoretical model suggested in Boot and Ratnovski (2016) predicts that banks with trading expertise allocate scares funds to scalable short-term securities trading rather than non-scalable long-term relationship lending activities, thus leading to lower credit supply. This channel appears to be at work for US banks but not for international banks. On the other hand, Shleifer and Vishny (2010) and Diamond and Rajan (2011) argue that banks with trading expertise redirect funds from lending to trading during periods of crisis as the returns from investing in distressed assets are higher than returns from lending. This channel appears to be at work both in US and international banks. These differences help in the assessment of differences in the regulatory frameworks regarding proprietary trading in the US and, e.g., the EU, with US regulations being significantly more restrictive than in other countries. Further exploiting our global sample, we also 
find that while trading banks provide less credit than non-trading banks overall, they tend to provide slightly more credit than non-trading banks abroad. However, during a crisis, trading banks also cut their foreign lending to a greater extent than their non-trading peers. Finally, we show that these spillovers from trading to credit supply have adverse consequences for the real economy as firms have reduced ability to invest in capital and expand their workforce. This last point in particular adds important information to the debate on the new regulations on banks' proprietary trading, as it shows that there are externalities of proprietary trading beyond excessive risk-taking by banks. Therefore, this finding constitutes the first step towards a cost-benefit analysis of regulations that restrict banks in their proprietary trading operations. However, our analysis also shows that real economic impact, while present, is limited. Since our sample consists of borrowers listed on stock exchanges, this suggests that these borrowers have the ability to compensate the reduced bank credit supply by other sources of funding. An extension of our analysis that also includes non-listed borrowers would likely be a fruitful avenue for future research. However, data on non-listed firms is difficult to obtain and is often only available for a limited number of European economies. Overall, our results suggest that the recent regulatory initiatives to separate trading from commercial banking activities, such as lending, are generally well advised, as banks that engage heavily in proprietary trading reduce their credit supply relative to other banks. Moreover, we show that a global perspective matters for the assessment of spillovers from trading to lending. 


\section{References}

Abbassi, P., Iyer, R., Peydro, J.L., Tous, F.R., 2016. Securities trading by banks and credit supply: Micro-evidence from the crisis. Journal of Financial Economics 121, 569-594.

Acharya, V.V., Eisert, T., Eufinger, C., Hirsch, C., 2018. Real Effects of the Sovereign Debt Crisis in Europe: Evidence from Syndicated Loans. Review of Financial Studies 31, 2855-2896.

Argote, L., Miron-Spektor, E., 2011. Organizational Learning: from experience to knowledge. Organization Science 22, 1123-1137.

Arping, S., 2013. Propreity Trading and the Real Economy. Tinbergen Institute Discussion Paper .

Bao, J., O’Hara, M., Zhou, X.A., Forthcoming. The Volcker Rule and corporate bond market making in times of stress. Journal of Financial Studies .

Blanchard, O.J., Das, M., Faruqee, H., 2010. The Initial Impact of the Crisis on Emerging Market Countries. Brookings Papers on Economic Activity, 263-307.

Blyth, C.R., 1972. On Simpson's Paradox and the Sure-Thing Principle. Journal of the American Statistical Association 67, 364-366.

Boot, A.W.A., Ratnovski, L., 2016. Banking and Trading. Review of Finance , 2219-2246.

Cingano, F., Manaresi, F., Sette, E., 2016. Does Credit Crunch Investment Down? New Evidence on the Real Effects of the Bank-Lending Channel. Review of Financial Studies 29, 2737-2773.

De Haas, R., Van Horen, N., 2012. Running for the Exit? International Bank Lending During a Financial Crisis. Review of Financial Studies 26, 244-285.

Diamond, D.W., 1991. Monitoring and Reputation: The Choice between Bank Loans and Directly Placed Debt. Journal of Political Economy 99, 689-721.

Diamond, D.W., Rajan, R.G., 2011. Fear of fire sales, illiquidity seeking, and credit freezes. The Quarterly Journal of Economcis 126, 557-591.

Dreher, A., 2006. Does globalization affect growth? Evidence from a new index of globalization. Applied Economics 38, 1091-1110.

Duffie, D., 2012. Market Making Under the Proposed Volcker Rule. Rock Center for Corporate Governance Stanford University Working Paper Serires No. 106.

Duffie, D., 2017. Financial Regulatroy Reform After the Crisis: An Assessment. Management Science, 1-23.

Erel, I., Julio, B., Kim, W., Weisbach, M.S., 2011. Macroeconomic Conditions and Capital Raising. Review of Financial Studies 25, 689-721.

Gobat, J., 2012. What Is a Bank? Finance \& Development 49, 38-39. 
Goldstein, M., Xie, D., 2009. The Impact of the Financial Crisis on Emerging Asia. Peterson Institute for International Economics Working Paper Series WP 09-11.

Gygli, S., Haelg, F., Sturm, J.E., 2018. The KOF Globalisation Index - Revisited. KOF Working Papers No. 439 .

Ivashina, V., 2005. Structure and Pricing of Syndicated Loans, in: The New York City Area Conference on Financial Intermediation jointly sponsored by the Federal Reserve Bank of New York and the Salomon Center. New York, N.Y.

Ivashina, V., Scharfstein, D., 2010. Bank lending during the financial crisis of 2008. Journal of Financial Economics 97, 319-338.

Iyer, R., Peydro, J.L., da Rocha-Lopes, Schoar, A., 2014. Interbank Liquidity Crunch and the Firm Credit Crunch: Evidence from the 2007-2009 Crisis. Review of Financial Studies 27, 347-372.

Jarmin, R.S., 1994. Learning by Doing and Competition in the Early Rayon Industry. The RAND Journal of Economics 25, 441-454.

Jimenez, G., Ongena, S., Peydro, J.L., Saurina, J., 2012. Credit Supply and Monetary Policy: Identifying the Bank Balance-Sheet Channel with Loan Applications. American Economic Review 102, 2301-2326.

Jimenez, G., Ongena, S., Peydro, J.L., Saurina, J., 2014. Hazardous Times for Monetary Policy: What Do Twenty-Three Million Bank Loans Say About the Effects of Monetary Policy on Credit Risk-Taking? Econometrica 82, 463-505.

Kahle, K.M., Stulz, R.M., 2013. Access to Capital, Investment, and the Financial Crisis. Journal of Financial Economics 110, 280-299.

Keat, H.S., 2009. The Global Financial Crisis: Impact on Asia and Poicy Challenges Ahead. Federal Reserve Bank of San Francisco Proceedings , 267-276.

Khwaja, A.I., Mian, A., 2008. Tracing the Impact of Bank Liquidity Shocks: Evidence from an Emerging Market. American Economic Review 98, 1413-1442.

Krahnen, J.P., Noth, F., Schüwer, U., 2017. Structural Reforms in Banking: The Role of Trading. Journal of Financial Regulation 3, 66-88.

Lehmann, M., 2016. Volcker rule, ring-fencing or separation of bank activities - Comparison of structural reform acts around the world. Journal of Banking Regulation 17, 176-187.

Marchetti, J., 2016. The International Banking Landscape: Developments, Drivers, and Potential Implications, in: Demirgüc-Kunt, A., Evanoff, D.D., Kaufman, G.G. (Eds.), The Future of Large, Internationally Active Banks. World Scientific Studies in International Economics 55. chapter 7, pp. 97-111. 
Merkley, J., Levin, C., 2011. The Dodd-Frank Act restrictions on proprietary trading and conflicts of interest: new tools to address evolving threats. Harvard Journal on Legislation 48, 515-553.

Monin, P., 2017. The OFR Financial Stress Index. Office of Financial Research Working Paper $17-04$.

Paravisini, D., Rappoport, V., Schnabl, P., 2015. Specialization in Bank Lending: Evidence from Exporting Firms. NBER Working Paper No 21800 .

Bonaccorsi di Patti, E., Sette, E., 2012. Bank balance sheets and the transmission of financial shocks to borrowers: evidence from the 2007-2008 crisis. Temi di discussione - Bank of Italy Working papers Number 848.

Reuters Business News, 2018. U.S. considering 'material changes' to 'Volcker Rule': Fed's Quarles. https://www.reuters.com/article/us-usa-fed-quarles/ u-s-considering-material-changes-to-volcker-rule-feds-quarles-idUSKBN1GH2U8. Accessed: 2018-05-21.

Schwert, M., 2018. Bank Capital and Lending Relationships. Journal of Finance 73, 787-830.

Shleifer, A., Vishny, 2010. Unstable banking. Journal of Financial Economics 97, 306-318.

Simpson, E.H., 1951. The Interpretation of Interaction in Contingency Tables. Journal of the Royal Statistical Society Series B, 238-241.

Stein, J.C., 2013. The Fire-Sales Problem and Securities Financing Transactions, in: Speech by Governor Jeremy C. Stein at the Federal Reserve Bank of New York Workshop on Fire Sales as a Driver of Systemic Risk in Triparty Repo and other Secured Funding Markets. New York, N.Y.

Sufi, A., 2007. Information asymetrie and financing arragements: Evidence from syndicated loans. Journal of Finance 62, 629-668.

Thompson, P., 2010. Learning by Doing, in: Hall, B.H., Rosenberg, N. (Eds.), Handbook of The Economics of Innovation. Elsevier. volume 1. chapter 10, pp. 429-476.

Veredas, D., Petkovic, A., 2010. Aggregation in linear models for panel data. Journal of the Japan Statistical Society 40, 63-95.

Whitehead, C.K., 2011. The Volcker Rule and Evolving Financial Markets. Harvard Business Law Review 1, 39-73.

Worstall, T., 2013. Banning Prop Trading By Banks: At Some Point It Becomes Banning Banking. https://www.forbes.com/sites/timworstall/2013/03/24/ banning-prop-trading-by-banks-at-some-point-it-becomes-banning-banking/ \#967ff4571f8a. Accessed: 2018-05-21. 
Appendix A. Appendix

Appendix A.1. Control Variables 


\section{Table A.1: Trading Expertise and Bank Lending - Control Variables}

NNotes: In this table, we present the results for the bank-level controls for the regressions reported in Table 5. The Capital Ratio is computed as common equity/total assets and the Loans-to-Deposits Ratio as total loans/total deposits. The Liquidity Ratio is computed as cash/total assets. Standard errors are clustered at the bank-firm cluster level. Significance levels: ${ }^{*} p<0.1 ;{ }^{* *} p<0.05 ;{ }^{* * *} p<0.01$.

\begin{tabular}{lcccccc}
\hline \hline & \multicolumn{5}{c}{ Dependent Variable: $\Delta \log ($ Loan Volume $)$} \\
\cline { 2 - 7 } & $(1)$ & $(2)$ & $(3)$ & $(4)$ & $(5)$ & $(6)$ \\
\hline $\log$ (Total Assets) & $0.499^{* * *}$ & $0.530^{* * *}$ & $0.531^{* * *}$ & $0.527^{* * *}$ & $0.531^{* * *}$ & $0.480^{* * *}$ \\
& $(0.012)$ & $(0.013)$ & $(0.013)$ & $(0.012)$ & $(0.013)$ & $(0.010)$ \\
ROA & 2.444 & 0.776 & -0.922 & $6.546^{* * *}$ & -0.968 & $26.922^{* * *}$ \\
& $(2.218)$ & $(2.229)$ & $(2.230)$ & $(1.637)$ & $(2.231)$ & $(1.455)$ \\
Liquidity Ratio & $0.744^{* *}$ & $0.781^{* *}$ & 0.417 & $0.417^{* *}$ & 0.415 & $-0.856^{* * *}$ \\
& $(0.302)$ & $(0.304)$ & $(0.297)$ & $(0.205)$ & $(0.297)$ & $(0.190)$ \\
Capital Ratio & $3.744^{* * *}$ & $2.967^{* * *}$ & $3.337^{* * *}$ & $2.259^{* * *}$ & $3.349^{* * *}$ & $-3.419^{* * *}$ \\
& $(0.588)$ & $(0.592)$ & $(0.594)$ & $(0.484)$ & $(0.595)$ & $(0.371)$ \\
Loans-To-Deposits & $0.195^{* * *}$ & $0.124^{* * *}$ & $0.150^{* * *}$ & $0.124^{* * *}$ & $0.151^{* * *}$ & $0.194^{* * *}$ \\
& $(0.033)$ & $(0.033)$ & $(0.032)$ & $(0.028)$ & $(0.032)$ & $(0.027)$ \\
\hline Observations & 268,910 & 268,910 & 268,910 & 268,910 & 268,910 & 268,910 \\
Adjusted R ${ }^{2}$ & 0.374 & 0.374 & 0.374 & 0.371 & 0.374 & 0.192 \\
\hline Firm Cluster-Year FE & YES & YES & YES & YES & YES & NO \\
Bank Country-Year FE & YES & YES & YES & NO & YES & NO \\
Firm Cluster FE & NO & NO & NO & NO & NO & YES \\
Bank Country & NO & NO & NO & YES & NO & YES \\
\hline \hline
\end{tabular}


Table A.2: Are Trading or Crisis Exposure Affect Capex? - Control Variables

Notes: In this table, we present the results concerning the control variables of the firm cluster level regressions on Capex. The unit of observation is firm cluster-year. The dependent variable is capital expenditure (Capex). The main results can be found in Table 6. All standard errors are clustered at the firm cluster level. Significance levels: ${ }^{*} p<0.1 ; \quad{ }^{* *} p<0.05 ; \quad{ }^{* * *} p<0.01$.

\begin{tabular}{|c|c|c|c|c|c|}
\hline & \multicolumn{5}{|c|}{ Dependent variable: Capex } \\
\hline & (1) & (2) & (3) & (4) & (5) \\
\hline $\log \left(\right.$ Assets $\left._{t-1}\right)$ & $\begin{array}{l}0.003^{* * *} \\
(0.0004)\end{array}$ & $\begin{array}{l}0.003^{* * *} \\
(0.0004)\end{array}$ & $\begin{array}{l}0.003^{* * *} \\
(0.0004)\end{array}$ & $\begin{array}{l}0.003^{* * *} \\
(0.0004)\end{array}$ & $\begin{array}{l}0.003^{* * *} \\
(0.0004)\end{array}$ \\
\hline Net Debt $_{t-1} /$ Assets $_{t-1}$ & $\begin{array}{l}-0.001 \\
(0.003)\end{array}$ & $\begin{array}{l}-0.001 \\
(0.003)\end{array}$ & $\begin{array}{l}-0.0005 \\
(0.003)\end{array}$ & $\begin{array}{c}-0.0005 \\
(0.003)\end{array}$ & $\begin{array}{c}-0.0005 \\
(0.003)\end{array}$ \\
\hline Intangible Assets $_{t-1} /$ Assets $_{t-1}$ & $\begin{array}{c}-0.057^{* * *} \\
(0.004)\end{array}$ & $\begin{array}{c}-0.057^{* * *} \\
(0.004)\end{array}$ & $\begin{array}{c}-0.057^{* * *} \\
(0.004)\end{array}$ & $\begin{array}{c}-0.057^{* * *} \\
(0.004)\end{array}$ & $\begin{array}{c}-0.057^{* * *} \\
(0.004)\end{array}$ \\
\hline$\Delta \operatorname{Cash}_{t-1} /$ Assets $_{t-1}$ & $\begin{array}{c}-0.051^{* * *} \\
(0.007)\end{array}$ & $\begin{array}{c}-0.051^{* * *} \\
(0.007)\end{array}$ & $\begin{array}{c}-0.051^{* * *} \\
(0.007)\end{array}$ & $\begin{array}{c}-0.051^{* * *} \\
(0.007)\end{array}$ & $\begin{array}{c}-0.051^{* * *} \\
(0.007)\end{array}$ \\
\hline EBITDA $_{t-1} /$ Assets $_{t-1}$ & $\begin{array}{c}0.612^{* * *} \\
(0.072)\end{array}$ & $\begin{array}{c}0.613^{* * *} \\
(0.072)\end{array}$ & $\begin{array}{c}0.611^{* * *} \\
(0.072)\end{array}$ & $\begin{array}{c}0.609^{* * *} \\
(0.072)\end{array}$ & $\begin{array}{c}0.608^{* * *} \\
(0.072)\end{array}$ \\
\hline Observations & 17,768 & 17,768 & 17,768 & 17,768 & 17,768 \\
\hline Adjusted $\mathrm{R}^{2}$ & 0.385 & 0.386 & 0.386 & 0.386 & 0.386 \\
\hline Country FE & YES & YES & YES & YES & YES \\
\hline Industry FE & YES & YES & YES & YES & YES \\
\hline Year FE & YES & YES & YES & YES & YES \\
\hline
\end{tabular}




\section{Table A.3: Are Trading or Crisis Exposure Affecting Employment Growth? - Control Variables}

Notes: In this table, we present the results concerning the control variables of the firm cluster level regressions on employment growth. The unit of observation is firm cluster-year. The dependent variable is employment growth, measured as the year-to-year change in the logarithm of the number of employees. The main results can be found in Table 7. All standard errors are clustered at the firm cluster level. Significance levels: ${ }^{*} p<0.1 ;{ }^{* *} p<0.05 ;{ }^{* * *} p<0.01$.

\begin{tabular}{|c|c|c|c|c|c|}
\hline & \multicolumn{5}{|c|}{ Dependent variable: Employment Growth $_{t}$} \\
\hline & $(1)$ & $(2)$ & (3) & (4) & $(5)$ \\
\hline $\log \left(\right.$ Assets $\left._{t-1}\right)$ & $\begin{array}{c}0.005^{* * *} \\
(0.001)\end{array}$ & $\begin{array}{c}0.005^{* * *} \\
(0.001)\end{array}$ & $\begin{array}{c}0.005^{* * *} \\
(0.001)\end{array}$ & $\begin{array}{c}0.005^{* * *} \\
(0.001)\end{array}$ & $\begin{array}{c}0.005^{* * *} \\
(0.001)\end{array}$ \\
\hline Net Debt $_{t-1} /$ Assets $_{t-1}$ & $\begin{array}{c}-0.018^{* *} \\
(0.008)\end{array}$ & $\begin{array}{c}-0.018^{* *} \\
(0.008)\end{array}$ & $\begin{array}{c}-0.018^{* *} \\
(0.008)\end{array}$ & $\begin{array}{c}-0.018^{* *} \\
(0.008)\end{array}$ & $\begin{array}{c}-0.018^{* *} \\
(0.008)\end{array}$ \\
\hline Intangible Assets $_{t-1} /$ Assets $_{t-1}$ & $\begin{array}{c}0.110^{* * *} \\
(0.011)\end{array}$ & $\begin{array}{c}0.110^{* * *} \\
(0.011)\end{array}$ & $\begin{array}{c}0.110^{* * *} \\
(0.011)\end{array}$ & $\begin{array}{c}0.109^{* * *} \\
(0.011)\end{array}$ & $\begin{array}{c}0.110^{* * *} \\
(0.011)\end{array}$ \\
\hline$\Delta$ Cash $_{t-1} /$ Assets $_{t-1}$ & $\begin{array}{c}0.436^{* * *} \\
(0.039)\end{array}$ & $\begin{array}{c}0.435^{* * *} \\
(0.039)\end{array}$ & $\begin{array}{c}0.435^{\text {*** }} \\
(0.039)\end{array}$ & $\begin{array}{c}0.437^{* * *} \\
(0.039)\end{array}$ & $\begin{array}{c}0.435^{* * *} \\
(0.039)\end{array}$ \\
\hline EBITDA $_{t-1} /$ Assets $_{t-1}$ & $\begin{array}{c}1.639^{* * *} \\
(0.233)\end{array}$ & $\begin{array}{c}1.641^{* * *} \\
(0.233)\end{array}$ & $\begin{array}{c}1.639^{* * *} \\
(0.233)\end{array}$ & $\begin{array}{c}1.677^{* * *} \\
(0.232)\end{array}$ & $\begin{array}{c}1.678^{* * *} \\
(0.232)\end{array}$ \\
\hline Observations & 17,768 & 17,768 & 17,768 & 17,768 & 17,768 \\
\hline Adjusted $\mathrm{R}^{2}$ & 0.060 & 0.060 & 0.060 & 0.061 & 0.060 \\
\hline Country FE & YES & YES & YES & YES & YES \\
\hline Industry FE & YES & YES & YES & YES & YES \\
\hline Year FE & YES & YES & YES & YES & YES \\
\hline
\end{tabular}


Table A.4: Effect of Trading on Loan Pricing - Control Variables

Notes: In this table, we present the results concerning the bank-level controls for the regressions reported in Table 8. The Capital Ratio is computed as common equity/total assets and the Loans-to-Deposits Ratio as total loans/total deposits. The Liquidity Ratio is computed as cash/total assets. Standard errors are clustered at the bank-firm cluster level. Significance levels: ${ }^{*} p<0.1 ;{ }^{* *} p<0.05 ; \quad{ }^{* * *} p<0.01$.

\begin{tabular}{lcccc}
\hline \hline & \multicolumn{4}{c}{ Dependent variable: $\Delta$ (All-in Spread Drawn) } \\
\cline { 2 - 5 } & $(1)$ & $(2)$ & $(3)$ & $(4)$ \\
\hline $\log$ (Total Assets) & $-0.728^{* * *}$ & $-0.714^{* * *}$ & $-0.725^{* * *}$ & $-0.715^{* * *}$ \\
& $(0.095)$ & $(0.093)$ & $(0.095)$ & $(0.093)$ \\
ROA & $82.363^{* *}$ & $77.198^{* *}$ & $84.371^{* *}$ & $78.460^{* *}$ \\
& $(39.267)$ & $(38.881)$ & $(39.395)$ & $(38.964)$ \\
Liquidity Ratio & -4.796 & -5.490 & -4.366 & -4.806 \\
& $(3.868)$ & $(3.856)$ & $(3.914)$ & $(3.926)$ \\
Capital Ratio & 1.311 & 1.914 & 0.816 & 0.954 \\
& $(6.938)$ & $(6.973)$ & $(6.972)$ & $(7.072)$ \\
Loans-To-Deposits & -0.324 & -0.264 & -0.311 & -0.264 \\
& $(0.347)$ & $(0.354)$ & $(0.348)$ & $(0.354)$ \\
\hline Observations & 203,947 & 203,947 & 203,947 & 203,947 \\
Adjusted R ${ }^{2}$ & 0.266 & 0.266 & 0.266 & 0.266 \\
\hline Bank Controls & YES & YES & YES & YES \\
Firm Cluster-Year FE & YES & YES & YES & YES \\
Bank Country & YES & YES & YES & YES \\
\hline \hline
\end{tabular}


Table A.5: Are U.S. banks different? (Sub-samples) - Control Variables

Notes: In this table, we present the results for the bank-level controls for the regressions reported in Table 9. The Capital Ratio is computed as common equity/total assets and the Loans-to-Deposits Ratio as total loans/total deposits. The Liquidity Ratio is computed as cash/total assets. Standard errors are clustered at the bank-firm cluster level. Significance levels: ${ }^{*} p<0.1 ;{ }^{* *} p<0.05 ;{ }^{* * *} p<0.01$.

\begin{tabular}{lcccc}
\hline \hline & \multicolumn{4}{c}{ Dependent variable: $\Delta \log ($ Loan Volume $)$} \\
\cline { 2 - 5 } & \multicolumn{2}{c}{ U.S. Banks } & $(1)$ & non-U.S. Banks \\
& $0.832^{* * *}$ & $0.773^{* * *}$ & $0.528^{* * *}$ & $0.534^{* * *}$ \\
log(Total Assets) & $(0.019)$ & $(0.017)$ & $(0.017)$ & $(0.015)$ \\
ROA & 3.510 & $23.307^{* * *}$ & $-14.764^{* * *}$ & -0.923 \\
& $(3.201)$ & $(2.782)$ & $(2.916)$ & $(1.946)$ \\
Liquidity Ratio & $1.479^{* *}$ & $4.244^{* * *}$ & $1.310^{* * *}$ & 0.300 \\
& $(0.672)$ & $(0.626)$ & $(0.332)$ & $(0.218)$ \\
Capital Ratio & $4.155^{* * *}$ & $-5.713^{* * *}$ & 0.477 & 0.894 \\
& $(0.988)$ & $(0.613)$ & $(0.775)$ & $(0.583)$ \\
Loans-To-Deposits & 0.115 & $0.299^{* * *}$ & $0.113^{* * *}$ & $0.084^{* * *}$ \\
& $(0.070)$ & $(0.061)$ & $(0.035)$ & $(0.030)$ \\
\hline Observations & 66,065 & 66,065 & 202,845 & 202,845 \\
Adjusted R ${ }^{2}$ & 0.407 & 0.272 & 0.384 & 0.379 \\
\hline Bank Controls & YES & YES & YES & YES \\
Firm Cluster-Year FE & YES & YES & YES & YES \\
Bank Country-Year FE & YES & NO & YES & NO \\
Bank Country & NO & YES & NO & YES \\
\hline \hline
\end{tabular}


Table A.6: Are U.S. banks different? (Single Equation) - Control Variables

Notes: In this table, we present the results concerning the bank-level controls for the regressions reported in Table 10. Instead of splitting the sample we introduce a US banks dummy variable and interact it with the \# Trading Memberships $>2$ dummy, the Financial Stress Index, and all bank-level controls. The upper part of the table shows the estimated coefficients if the US banks dummy equals zero, and the lower part shows the estimated coefficients if the US banks dummy is equal to one. The Capital Ratio is computed as common equity/total assets and the Loans-to-Deposits Ratio as total loans/total deposits. The Liquidity Ratio is computed as cash/total assets. Standard errors are clustered at the bank-firm cluster level. Significance levels: ${ }^{*} p<0.1 ;{ }^{* *} p<0.05 ;{ }^{* * *} p<0.01$.

Dependent variable: $\Delta \log ($ Loan Volume $)$

(1)

(2)

U.S. Banks Dummy $=0$

$\log$ (Total Assets)

0.523

$0.528^{* * *}$

$(0.015)$

$(0.015)$

ROA

0.573

$-0.439$

Liquidity Ratio

(1.893)

(1.908)

0.217

0.330

(0.211)

$(0.213)$

Capital Ratio

$1.297^{* *}$

$1.433^{* *}$

$(0.557)$

$(0.560)$

Loans-To-Deposits

$0.061^{* *}$

$0.074^{* *}$

(0.029)

(0.030)

U.S. Banks Dummy = 1

$\log$ (Total Assets)

0.033

0.026

(0.023)

$(0.023)$

ROA

$11.299^{* * *}$

$12.560^{* * *}$

(3.144)

(3.611)

Liquidity Ratio

0.464

0.302

$(0.644)$

$(0.645)$

Capital Ratio

$-0.915$

$-1.520^{*}$

$(0.772)$

$(0.790)$

Loans-To-Deposits

0.060

0.050

(0.064)

(0.064)

\begin{tabular}{lcc}
\hline Observations & 268,910 & 268,910 \\
Adjusted R & 0.372 & 0.373 \\
\hline Bank Controls & YES & YES \\
Firm Cluster-Year FE & YES & YES \\
Non-U.S. Bank Country Dummies & YES & YES \\
\hline \hline
\end{tabular}


Table A.7: Is foreign lending affected differently by trading expertise? - Control Variables

Notes: In this table, we present the results concerning the bank-level controls for the regressions reported in Table 12. The Capital Ratio is computed as common equity/total assets and the Loans-to-Deposits Ratio as total loans/total deposits. The Liquidity Ratio is computed as cash/total assets. Standard errors are clustered at the bank-firm cluster level. Significance levels: ${ }^{*} p<0.1 ;{ }^{* *} p<0.05 ; \quad{ }^{* * *} p<0.01$.

\begin{tabular}{|c|c|c|c|c|c|c|}
\hline & \multicolumn{6}{|c|}{ Dependent variable: $\Delta \log ($ Loan Volume $)$} \\
\hline & (1) & (2) & (3) & (4) & (5) & (6) \\
\hline \multirow[t]{2}{*}{$\log$ (Total Assets) } & $0.687^{* * *}$ & $0.675^{* * *}$ & $0.699^{* * *}$ & $0.688^{* * *}$ & $0.582^{* * *}$ & $0.573^{* * *}$ \\
\hline & $(0.012)$ & $(0.011)$ & $(0.012)$ & $(0.011)$ & $(0.012)$ & $(0.012)$ \\
\hline \multirow[t]{2}{*}{ ROA } & $-6.649^{* * *}$ & 1.080 & $-7.217^{* * *}$ & 0.628 & -2.497 & $3.997^{* *}$ \\
\hline & $(2.045)$ & $(1.533)$ & $(2.038)$ & $(1.530)$ & $(2.173)$ & $(1.615)$ \\
\hline \multirow[t]{2}{*}{ Liquidity Ratio } & $2.115^{* * *}$ & $1.547^{* * *}$ & $2.249^{* * *}$ & $1.638^{* * *}$ & $0.991^{* * *}$ & $0.744^{* * *}$ \\
\hline & $(0.293)$ & $(0.203)$ & $(0.292)$ & $(0.203)$ & $(0.298)$ & $(0.205)$ \\
\hline \multirow[t]{2}{*}{ Capital Ratio } & $4.721^{* * *}$ & $4.176^{* * *}$ & $4.806^{* * *}$ & $4.310^{* * *}$ & $3.780^{* * *}$ & $3.050^{* * *}$ \\
\hline & $(0.556)$ & $(0.459)$ & $(0.556)$ & $(0.459)$ & $(0.582)$ & $(0.478)$ \\
\hline \multirow[t]{2}{*}{ Loans-To-Deposits } & $0.096^{* * *}$ & $0.077^{* * *}$ & $0.083^{* * *}$ & $0.066^{* *}$ & $0.110^{* * *}$ & $0.093^{* * *}$ \\
\hline & $(0.032)$ & $(0.028)$ & $(0.032)$ & $(0.028)$ & $(0.032)$ & $(0.028)$ \\
\hline Observations & 268,910 & 268,910 & 268,910 & 268,910 & 266,317 & 266,317 \\
\hline Adjusted $\mathrm{R}^{2}$ & 0.413 & 0.409 & 0.416 & 0.412 & 0.386 & 0.382 \\
\hline Bank Controls & YES & YES & YES & YES & YES & YES \\
\hline Firm Cluster-Year FE & YES & YES & YES & YES & YES & YES \\
\hline Bank Country-Year FE & YES & NO & YES & NO & YES & NO \\
\hline Bank Country & NO & YES & NO & YES & $\mathrm{NO}$ & YES \\
\hline
\end{tabular}




\section{Appendix A.2. Estimating the Fixed-Effects Models on Aggregated Observations}

We now discuss the implications of applying our model (1) and model (2) regressions to firm clusters rather than individual firms. This appendix relies heavily on Veredas and Petkovic (2010). Generally, we are interested in estimating a model in the following form:

$$
y_{z, t}=\gamma_{z}+\beta f_{z, t}+u_{z, t}
$$

where $z=1,2, \ldots, Z$ indexes individual firms. However, as in our specifications for model (1) and model (2), we must aggregate individual firms into groups $j=1,2, \ldots, J$ with $J<Z$. Thus, we define an aggregation scheme, such that

$$
\tilde{y}_{j, t}=\sum_{z=1}^{Z} M_{z}^{j} y_{z, t}
$$

where $M_{z}^{j}=1$ or 0 , such that $\sum_{j=1}^{J} \sum_{z=1}^{Z} M_{z}^{j}=J$, i.e., we sum up individuals belonging to group $j$. We further require $\sum_{z=1}^{Z} M_{z}^{j} M_{z}^{j^{\prime}}=0 \forall a^{\prime} \neq a$, i.e., that individual firms can only belong to one group. Without loss of generality, we consider a simplified case with only a single independent variable and only individual fixed effects. We focus on a specification equivalent to our model (2). All results shown below are easy to apply to our model (1) specification.

Applying this aggregation scheme to the regression equation, (A.1) yields

$$
\begin{aligned}
\sum_{z=1}^{Z} M_{z}^{j} y_{z, t} & =\sum_{z=1}^{Z} M_{z}^{j} \gamma_{z}+\sum_{z=1}^{Z} \beta M_{z}^{j} f_{z, t}+\sum_{z=1}^{Z} M_{z}^{j} u_{z, t} \\
\tilde{y}_{j, t} & =\gamma_{j}+\beta \tilde{f}_{j, t}+\tilde{u}_{j, t}
\end{aligned}
$$

Thus, the slope parameter is not affected by the aggregation, as we assume slopes are constant through individual firms. The group fixed effects $\gamma_{j}$ are simply the sum of the individual fixed effects in each group. Note that in terms of our model ((1), we have $\tilde{x}_{i, t}=x_{i, t}$, since the control variables are bank-level rather than firm-level variables, and $\sum_{z=1}^{Z} M_{z}^{j}=1 .^{27}$

To understand how the aggregation affects parameter estimation and inference, we write the model in matrix notation.

$$
\begin{aligned}
\left\{\begin{array}{c}
\mathbf{y}_{\mathbf{1}} \\
\mathbf{y}_{\mathbf{2}} \\
\vdots \\
\mathbf{y}_{\mathbf{Z}}
\end{array}\right\} & =\left\{\begin{array}{c}
\gamma_{1} \mathbf{e}_{\mathbf{N}} \\
\gamma_{2} \mathbf{e}_{\mathbf{N}} \\
\vdots \\
\gamma_{\mathbf{Z}} \mathbf{e}_{\mathbf{N}}
\end{array}\right\}+\left\{\begin{array}{c}
\mathbf{f}_{\mathbf{1}} \\
\mathbf{f}_{\mathbf{2}} \\
\vdots \\
\mathbf{f}_{\mathbf{Z}}
\end{array}\right\} \beta+\left\{\begin{array}{c}
\mathbf{u}_{\mathbf{1}} \\
\mathbf{u}_{\mathbf{2}} \\
\vdots \\
\mathbf{u}_{\mathbf{Z}}
\end{array}\right\} \\
\mathbf{Y} & =\mathbf{G}+\mathbf{F} \beta+\mathbf{U}
\end{aligned}
$$

where $\mathbf{y}_{\mathbf{z}}$ and $\mathbf{f}_{\mathbf{z}}$ are $(N \times 1)$ vectors containing the observations for individual firm $z . \gamma_{z}$ are individual firm fixed effects and $\mathbf{e}_{\mathbf{N}}$ are $(N \times 1)$ vectors of ones. $\mathbf{u}_{\mathbf{z}}$ are $(N \times 1)$ vectors of iid

\footnotetext{
${ }^{27}$ Obviously, the same applies to the bank country-year fixed effect.
} 
individual firm error terms with $\mathbb{E}\left(\mathbf{u}_{\mathbf{z}}\right)=\mathbf{0}$ and $\mathbb{E}\left(\mathbf{u}_{\mathbf{z}} \mathbf{u}_{\mathbf{z}}^{\prime}\right)=\sigma_{u}^{2} \mathbf{I}_{\mathbf{N}}$, where $\mathbf{I}_{\mathbf{N}}$ is an identity matrix of size $\mathrm{N}$.

We introduce our aggregation scheme by defining the following matrix:

$$
\mathbf{M}=\left\{\begin{array}{cccc}
M_{1}^{1} & M_{2}^{1} & \cdots & M_{Z}^{1} \\
M_{1}^{2} & M_{2}^{2} & \cdots & M_{Z}^{2} \\
\vdots & \vdots & \ddots & \vdots \\
M_{1}^{J} & M_{2}^{J} & \cdots & M_{Z}^{J}
\end{array}\right\}
$$

Hence, the aggregation in Equation (A.2) can be written in matrix notation as $\left(\mathbf{M} \otimes \mathbf{I}_{\mathbf{N}}\right) \mathbf{Y}$. With $\mathbf{A}=\left(\mathbf{M} \otimes \mathbf{I}_{\mathbf{N}}\right)$, we can write Equation (A.4) as

$$
\mathbf{A Y}=\mathbf{A G}+\mathbf{A F} \beta+\mathbf{A U}
$$

Therefore, it follows directly that we have

$$
\mathbb{E}\left(\mathbf{A} \mathbf{U U}^{\prime} \mathbf{A}^{\prime}\right)=\sigma_{u}^{2}\left(\mathbf{A} \mathbf{A}^{\prime} \otimes \mathbf{I}_{\mathbf{N}}\right)
$$

where $\sigma_{u}^{2}=\mathbb{E}\left(\mathbf{U U}^{\prime}\right)$. Hence, the aggregation of firms into firm clusters produces heteroscedastic error terms, since the values along the diagonal of $\mathbb{E}\left(\mathbf{A} \mathbf{U U}^{\prime} \mathbf{A}^{\prime}\right)$ differ.

To estimate the coefficient $\beta$ we define a standard projection matrix $\mathbf{Q}$ to de-mean observations

$$
\begin{array}{r}
\mathbf{Q}=\mathbf{I}_{\mathbf{N}}-\frac{1}{N} \mathbf{e}_{\mathbf{N}} \mathbf{e}_{\mathbf{N}}^{\prime} \\
\tilde{\mathbf{Q}}=\mathbf{I}_{\mathbf{Z}} \otimes \mathbf{Q}
\end{array}
$$

Thus, we have

$$
\begin{aligned}
\tilde{\mathbf{Q}} \mathbf{A Y} & =\tilde{\mathbf{Q}} \mathbf{A} \mathbf{G}+\tilde{\mathbf{Q}} \mathbf{A} \mathbf{F} \beta+\tilde{\mathbf{Q}} \mathbf{A} \mathbf{U} \\
& =\tilde{\mathbf{Q}} \mathbf{A} \mathbf{F} \beta+\tilde{\mathbf{Q}} \mathbf{A} \mathbf{U}
\end{aligned}
$$

Therefore, it follows directly that the estimated coefficient has the following form:

$$
\hat{\beta}=\left(\mathbf{F}^{\prime} \mathbf{A}^{\prime} \tilde{\mathbf{Q}} \mathbf{A F}\right)^{-1} \mathbf{F}^{\prime} \mathbf{A}^{\prime} \tilde{\mathbf{Q}} \mathbf{A} \mathbf{U}
$$

Since $\mathbb{E}(\mathbf{U})=\mathbf{0}$, we have $\mathbb{E}(\hat{\beta}-\beta)=0$, i.e., the estimator is unbiased. However, the estimator is inefficient due to the aggregation and the fixed effects specification, i.e., we have, for the variance of $\hat{\beta}$,

$$
\begin{aligned}
\mathbb{E}\left[(\hat{\beta}-\beta)(\hat{\beta}-\beta)^{\prime}\right] & = \\
& =\left(\mathbf{F}^{\prime} \mathbf{A}^{\prime} \tilde{\mathbf{Q}} \mathbf{A} \mathbf{F}\right)^{-1} \mathbf{F}^{\prime} \mathbf{A}^{\prime} \tilde{\mathbf{Q}} \mathbb{E}\left(\mathbf{A} \mathbf{U}^{\prime} \mathbf{A}^{\prime}\right) \tilde{\mathbf{Q}} \mathbf{A} \mathbf{F}\left(\mathbf{F}^{\prime} \mathbf{A}^{\prime} \tilde{\mathbf{Q}} \mathbf{A F}\right)^{-1} \\
& =\sigma_{u}^{2}\left(\left(\mathbf{F}^{\prime} \mathbf{A}^{\prime} \tilde{\mathbf{Q}} \mathbf{A} \mathbf{F}\right)^{-1} \mathbf{F}^{\prime} \mathbf{A}^{\prime} \tilde{\mathbf{Q}}\left(\mathbf{A} \mathbf{A}^{\prime} \otimes \mathbf{I}_{\mathbf{N}}\right) \tilde{\mathbf{Q}} \mathbf{A} \mathbf{F}\left(\mathbf{F}^{\prime} \mathbf{A}^{\prime} \tilde{\mathbf{Q}} \mathbf{A} \mathbf{F}\right)^{-1}\right)
\end{aligned}
$$




\section{Appendix A.3. Institutional Details}

The fact that regulators in many countries have taken action suggests that they believe in the existence of this link. Since the 2007-2009 financial crisis, various regulatory initiatives have been launched to insulate the traditional banking business - such as lending and deposit-taking - from securities trading, including the Volcker Rule in the US, the Banking Reform Act 2013 in the UK, and the Liikanen proposal in the EU.

In the US, the Volcker Rule was introduced in 2010 as part of the Dodd-Frank Act, which prohibits banks from engaging in propriety trading. ${ }^{28}$ The Volcker Rule exempts certain securities, such as foreign exchange instruments and government securities, hedging, and market-making activities. ${ }^{29}$ Since July 2014 , banks with trading assets and liabilities worth $\$ 50$ billion or more have to comply with Volcker Rule regulations, and banks with smaller trading operations are exempt until $2016 .^{30}$

In the UK, the Banking Reform Act 2013, which builds on the Vickers Report, introduced a partial separation of retail banking services from wholesale and investment banking - the so-called "ring-fencing" - to prevent banks from funding securities trading through deposits. ${ }^{31}$ The UK government implemented all the necessary legislation in 2015, but the Prudential Regulation Authority has yet to finalize the ring-fencing rules. UK banks are expected to comply with the regulations by 2019 at the latest. ${ }^{32}$

In the EU, the Liikanen proposal ${ }^{33}$ suggests two options for reform in concerning securities trading. According to the first option, banks are broken up into separate units, engaging in trading and traditional banking only, if they fail to present to regulators a credible resolution plan, detailing how trading-related activities can be identified and separated during a financial crisis. Moreover, additional non-risk-weighted capital requirements are imposed on banks that engage in securities trading. According to the second option, large and complex banks are broken up by forcing their trading activities into legally separate units. The separate "Trading-houses" may be placed in the same ownership structure, but they must have their own equity and separate funding that cannot come from (government-insured) retail deposit-taking. The implementation of the proposed reforms moves more slowly in the EU. The EU council agreed in 2015 on its position regarding the proposed regulations, which provides the Council President with the necessary mandate to negotiate with the European Parliament on the final version thereof. However, Germany and France independently pushed forward, introducing national regulations on banks' trading activities in 2013. Banks in both countries have been required to comply with the regulations since July 2015. Both

\footnotetext{
${ }^{28}$ The rule is named after its author and primary proponent Paul Volcker, who served as chairman of the Economic Recovery Advisory Board and was former Federal Reserve chairman.

${ }^{29}$ See Duffie (2017).

${ }^{30}$ See, e.g., Krahnen et al. (2017) and Lehmann (2016). Whitehead (2011) provides a comprehensive discussion of the legal concerning the Volcker Rule provisions.

${ }^{31}$ The report is named after Sir John Vickers, then Chair of the UK's Independent Commission on Banking, who authored the report on behalf of the UK parliament.

${ }^{32}$ See Krahnen et al. (2017).

${ }^{33}$ The Liikanen proposal refers to the policy suggestions that were made in the "Report of the European Commission's High-level Expert Group on Bank Structural Reform". The expert group was headed by Erkki Liikanen, governor of the Bank of Finland and member of the ECB council, and it became known as the Liikanen group.
} 
Germany and France, follow the second option of reform in the Liikanen proposal, allowing banks to continue their securities trading activities but only to exercise them through legally separate entities, which can be placed in the same ownership structure. While largely similar, the German and French regulations differ in the precise definition of the activities from which the non-trading entities are banned. ${ }^{34}$ Since the current EU proposal includes a clause that allows national laws to remain in place after the EU regulations become effective, the relationship between EU and national legislation is not clear in this regard. ${ }^{35}$

The above mentioned legislation aims to distinguish proprietary trading, i.e., securities trading on a banks' own account with the intention to profit from the difference between the sales and purchase price, from market-making and hedging. However, Worstall (2013) explains that many transactions that can be framed as proprietary trading share the same characteristics as the maturity transformation (accepting short-term deposits to fund long-term lending) on which traditional banking is built as well as a wide range of hedging activities. Hence, the main challenge faced by regulators tasked with the implementation of the above mentioned rules is to provide a clear and operational definition of the type of securities trading that is to be banned or separated from traditional banking. Furthermore, Duffie (2012) and Duffie (2017) argue that in fact there is no evident distinction between proprietary trading and market-making. Investors rely on the ability of market makers to buy securities or sell them out of their inventory. Most market-making around the world is conducted by bank-affiliated broker-dealers who handle the majority of trading in government, municipality, and corporate bonds as well as over-the-counter derivatives, currencies, commodities, mortgage-related securities, and large blocks of equities. Therefore, enforcing the different regulations regarding propriety trading could lead to a reduction in market-making by banks, potentially leading to losses in market liquidity and eventually a migration of market-making into the less-regulated shadow banking sector. ${ }^{36}$ Furthermore, Randal Quarles, current Federal Reserve Vice Chair for Supervision, made a similar point when announcing a review of the Volcker Rule in March 2018, arguing that "We [the Federal Reserve] want banks to be able to engage in market making and provide liquidity to financial markets with less fasting and prayer about their compliance with the Volcker Rule". 37 Consistent with these concerns, Bao, O'Hara and Zhou (Forthcoming) demonstrate that Volcker Rule-affected broker-dealers reduced market-making activities, leading to lower liquidity in the bond market during periods of stress. Thus, there is a cost-benefit tradeoff of regulations regarding securities trading by banks. Our results contribute to the debate by providing evidence for a reduction in credit supply across various jurisdictions as well as negative consequences of banks' securities trading for the real economy.

\footnotetext{
${ }^{34}$ See Lehmann (2016).

${ }^{35}$ See Krahnen et al. (2017).

${ }^{36}$ See Duffie (2012) and Duffie (2017).

${ }^{37}$ See Reuters Business News (2018).
} 